\title{
30. MILANKOVITCH CYCLES IN UPPER JURASSIC AND LOWER CRETACEOUS RADIOLARITES OF THE EQUATORIAL PACIFIC: SPECTRAL ANALYSIS AND SEDIMENTATION RATE CURVES ${ }^{1}$
}

\author{
Alain J. Molinie² and James G. Ogg ${ }^{3}$
}

\begin{abstract}
Periodic changes in depositional environments due to Milankovitch astronomical climate cycles can cause cyclic patterns in sedimentation properties as recorded by logging data. Ocean Drilling Program Site 801 recovered Callovian (upper Middle Jurassic) through Valanginian (Lower Cretaceous) clayey radiolarites, originally deposited in a near-equatorial setting. Cycles of variable concentration of radiolarians and clay, and associated changes in degree of silicification were apparent in the geophysical logs, especially in the gamma-ray signal and the Formation MicroScanner. Three-dimensional spectral analysis was performed on the gamma-ray log signal using a 40-m sliding window. The dominant spectral peaks maintain the same relative ratios in frequency as the 413-k.y., 123-k.y., and 95-k.y. Milankovitch periods of eccentricity. The wavelengths of these eccentricity-modulated cycles were used to determine rates and discontinuities in sedimentation with depth.

Two sharp discontinuities in sedimentation rate were inferred: (1) Callovian alternations of red radiolarite and claystone, with a sedimentation rate of approximately 14.5 m.y., is terminated by a Callovian/Oxfordian boundary hiatus, and the overlying upper Oxfordian through lowest Tithonian clay-rich radiolarites and the lower Tithonian banded chert have an average sedimentation rate of $7 \mathrm{~m} / \mathrm{m} . y . ;$ (2) a discontinuity of probable late Tithonian-early Berriasian age terminates the Tithonian banded chert; the overlying Berriasian through Valanginian radiolarite has a mean sedimentation rate of $11.5 \mathrm{~m} / \mathrm{m} . \mathrm{y}$. These computed sedimentation rates and interpreted discontinuities are consistent with the stratigraphy of the recovered sediments and the uncertainties in the geological time scale.

Eccentricity cycles identified in the gamma-ray signal were matched to corresponding features on the Formation MicroScanner high-resolution imagery of clay content and degree of silicification. Eccentricity cycles are manifested as groupings of beds of higher radiolarian content and silicification. Milankovitch climate cycles may affect the intensity of equatorial Pacific upwelling, hence the surface productivity of radiolarians, and the amount of eolian dust and clay contributed to the sediments.
\end{abstract}

\section{MILANKOVITCH CLIMATE CYCLES AND OCEANIC SEDIMENTS}

Sediment accumulation rates are generally determined by estimating the elapsed time between identified biostratigraphic events and the corresponding thickness between these biostratigraphic levels. This procedure requires an absolute time scale and will generally yield a minimum average sedimentation rate due to the difficulty of compensating for hiatuses or for partial presence of the constraining biostratigraphic zones. On the other hand, pulses of rapid accumulation due to slumping and turbidite deposition may result in computed sedimentation rates that are significantly higher than the actual sedimentation of the in-situ beds. Some sediments contain an internal "clock" created by the systematic variation of depositional facies in response to periodic changes in the Earth's orbital parameters: precession, obliquity, and eccentricity. In such cases, spectral analysis of logging signals or other geophysical and geochemical measurements can identify these regular cycles and be related to these known "Milankovitch" periodicities, thereby providing actual sedimentation rates (e.g., Park and Herbert, 1987; Jarrard and Arthur, 1989; Molinie et al., 1990).

Milankovitch cycles are quasi-periodic variations in the Earth's orbital parameters of precession, obliquity, and eccentricity which in turn affect the seasonal and annual latitudinal distribution of solar insolation and long-term global and hemispheric climates (Milankovitch, 1920, 1941; Imbrie and Imbrie, 1980). Obliquity, the amount of axial tilt with respect to the Sun, varies with a period of $41 \mathrm{k.y}$. from $22^{\circ}$ to $24.5^{\circ}$ (presently $23.45^{\circ}$ ) and increases in importance at higher latitudes (Berger,

\footnotetext{
'Larson, R. L., Lancelot, Y., et al., 1992. Proc. ODP, Sci. Results, 129: College Station, TX (Ocean Drilling Program).

${ }^{2}$ Borehole Research Group, Lamont-Doherty Geological Observatory, Palisades, NY 10964, U.S.A.

${ }^{3}$ Department of Earth and Atmospheric Science, Purdue University, West Lafayette, IN 47907 , U.S.A.
}

1984). Precession, which governs the relative direction of tilt with respect to the closest approach to the Sun, affects the contrast between summer and winter seasons in each hemisphere and varies with periods of 19 k.y. and 23 k.y. Eccentricity of the Earth's orbit primarily modulates the importance of precession and displays an irregular variation ranging between 0.0005 and 0.0607 (presently 0.0167 ), which is approximated by a combination of 95-k.y., 123-k.y., and 413-k.y. periodicities. The increase of the semi-major axis of the lunar orbit with time implies that periodicities of obliquity and precession were probably slightly shortened in the past, with the present set of 19-23-41 k.y. periods possibly being 17.6-21-35 k.y. in the early Permian (270 Ma). However, there is considerable uncertainty caused by inaccuracies in our knowledge of the rotation rate of the Earth (Berger et al., 1989).

The combined effect of insolation variations from the precessionobliquity-eccentricity cycles have been statistically implicated as the driving factor of Pleistocene glacial episodes, although enhancement mechanisms must be present to account for the magnitude of these climate changes (Hays et al., 1976; Imbrie and Imbrie, 1980; Pisias and Moore, 1981; Imbrie et al., 1984; Berger et al., 1984). In particular, the dominance of eccentricity periods of $100 \mathrm{k} . \mathrm{y}$. in governing the timing of major glacial ages conflicts with the theoretically minor importance of eccentricity variations on latitudinal insolation and global climate (Kominz and Pisias, 1979; Imbrie and Imbrie, 1980; Saltzman and Maasch, 1988; Oglesby and Park, 1989; Maasch and Saltzman, 1990). In any event, oscillations of oceanic surface-water and bottom-water temperatures and of carbonate productivity and preservation during much of the Cenozoic appear to be responses to Milankovitch climate cycles (e.g., Dean et al., 1978; Dean et al., 1981; Arthur et al., 1984; Schwarzacher, 1987; Raymo et al., 1989). The potential of using such regular sedimentary cycles for measuring sedimentation rates and "tuning" absolute time scales was first recognized by Gilbert (1895) and has been applied to various deep-sea and continental formations of the Tertiary and Mesozoic (e.g., Hays et al., 1976; Fischer, 1980; de Boer, 1983; Imbrie et al., 1984; Arthur 
et al., 1984; Anderson, 1984; House, 1985; Olsen, 1986; Herbert et al., 1986; Herbert and Fischer, 1986; Fischer, 1986; Bottjer et al., 1986; Park and Herbert, 1987; Schwarzacher, 1987; Cotillon, 1987; Ogg et al., 1987; ten Kate and Sprenger, 1989; Dromart, 1989; Herbert and D'Hondt, 1990).

Milankovitch climatic cycles played a major role in Atlantic-Tethyan oceanic sedimentation during the Early Cretaceous as manifest by alternations of bioturbated limestone and of laminated marl or calcareous claystone (e.g., Lancelot et al., 1972; Freeman and Enos, 1978; Jansa et al., 1979; Cotillon et al., 1980; Robertson and Bliefnick, 1983; Cotillon and Rio, 1984; Cotillon, 1984, 1987; Baltuck, 1987; Ogg et al., 1987). These cycles of carbonate content and bioturbation have spectral periodicities similar to those of precession, obliquity and eccentricity (Huang, 1991), and may have been caused primarily by fluctuations in surface productivity and in dissolved-oxygen levels of bottom waters (Cotillon, 1984; Ogg et al., 1987). During the high sea levels of the Aptian and later stages of the mid-Cretaceous, similar limestone-marl cycles were important in the flooded interior of North America and on margins of the Atlantic and Tethys oceans. In addition to changing surface-water productivity and bottom-water oxygenation, climate-governed fluctuations in runoff and clay input from the adjacent landmasses may have played a major role in formation of such cycles in continental margin or epicontinental sea environments (e.g., Gilbert, 1895; Fischer, 1980; Pratt, 1981; de Boer, 1983; de Boer and Wonders, 1984; Arthur et al., 1984; Barron et al., 1985; Herbert et al., 1986; Pratt and King, 1986; Hattin, 1986; Oglesby and Park, 1989; ten Kate and Sprenger, 1989).

Prior to Ocean Drilling Program (ODP) Leg 129, the Early Cretaceous pelagic sediment history of the Pacific Ocean was known primarily from Deep Sea Drilling Project (DSDP) sites located at paleolatitudes several degrees from the paleoequator or on oceanic plateaus. Radiolarian-rich limestones recovered at these Pacific DSDP sites displayed indications of cyclic carbonate deposition (Shipboard Scientific Party, 1973; Larson et al., 1975; Thiede et al., 1981; Cotillon, 1984, 1987).

At Site 800 of Leg 129, we recovered Lower Cretaceous interbedded radiolarian sands and claystones having rhythmic alternations on the order of 5-10 cm or approximately 10 - to $30-\mathrm{k}$.y. periodicity, suggesting a correspondence with precession-induced climatic-oceanic changes (Shipboard Scientific Party, 1990b; Ogg et al., this volume). However, Site 800 had inadequate core recovery and logging coverage to perform spectral analysis on this facies. Site 801 displays similar 5 - to $10-\mathrm{cm}$ alternations in clay content and silicification of Jurassic through Lower Cretaceous radiolarites. The extensively logging of this site enabled spectral analysis of multi-meter modulations of these alternations.

Jurassic and Lower Cretaceous deep-sea sediments uplifted on the accreting margins of the Pacific consist almost exclusively of thinbedded radiolarian cherts (Iijima et al., 1983; Hein and Karl, 1983; Jones and Murchey, 1986; Baumgartner, 1987). The rhythmic bedding of some "ribbon" radiolarites in the Pacific and Tethyan regions may perhaps reflect Milankovitch climatic cycles or other periodic control of radiolarian productivity (Garrison and Fischer, 1969; Fischer, 1977), but other processes, such as redeposition and rhythmic diagenesis, are probably also operating (McBride and Folk, 1979; Jenkyns and Winterer, 1982; Baltuck, 1983; Steinberg et al., 1983).

In near-equatorial latitudes, climatic changes caused by precession cycles should be more important than obliquity cycles, with eccentricity cycles acting to enhance or diminish the magnitude of the precession effect (e.g., McIntyre et al., 1989; Oglesby and Park, 1989). The precession cycle governs the seasonal contrast in mean temperatures in each hemisphere. The changes in summer/winter contrast and corresponding alteration in seasonal equator-pole temperature gradient should affect the seasonality and strength of trade winds, the position of the Inter-Tropical Convergence Zone, the position and intensity of equatorial upwelling and corresponding radiolarian productivity, and the continental climate and source of eolian dust delivered to the ocean. In some aspects, the precession effects in the equatorial Pacific and adjacent continents would display some similarities to a long-term El Niño-type cycle in some of its main oceanographic and climatic features, although the driving causes are quite different. The eccentricity enhancement of the precession cycle may imply that times of accentuated eccentricity correspond to increased equatorial upwelling and radiolarian influx to the sediments. It is probable that the clay influx to the sediments, which probably has a high eolian component (e.g., Leinen, 1989; Janecek and Rea, 1983), would also vary with the eccentricity-precession cycle.

The response of depositional environments to Milankovitch climatic cycles is periodic in time. In contrast, the observed sedimentary record is a function of depth. If a sediment has a relatively constant long-term rate of accumulation, then the variation of its constituents with depth (expressed as cycles/meter) will approximate their variation with time (expressed as cycles/million years). In such cases, spectral analysis of the depth series within this interval will detect temporal cycles. Spectral analysis of a sedimentary section yields cycle frequencies as measured in cycles/meter, and requires that the spacing between cycles must be consistent.

To demonstrate that the observed cycles have Milankovitch orbital periodicities - a necessary requirement before applying this internal clock - two methods can be used. The most common method is to estimate the periods of the sediment cycles by applying a sedimentation rate estimated from the available biostratigraphic data. If the computed cycle periods are similar to those of Milankovitch climate cycles, then the corresponding Milankovitch periods are used to "tune" the sedimentation rate. An alternate technique is to compare the ratios of the observed sediment cycle wavelengths to the ratios of Milankovitch time periods (e.g., Park and Herbert, 1987). For example, if the spectral analysis of a formation displays three main cycles having ratios of wavelengths nearly identical to the ratios of the 413-123-95 k.y. set of major eccentricity cycles, then these cycles are probably a reflection of those eccentricity cycles. This ratio technique does not require precise biostratigraphy or an absolute time scale, but requires a clear spectral signal for distinguishing the presence of the different cycles. These two methods are generally combined, using the available biostratigraphic data as a constraint on the interpretation of the Milankovitch orbital periodicities, because some ratios are not unique (for instance, the ratio of the 123-k.y./95-k.y. eccentricity cycles is very similar to that of the 23-k.y./19-k.y. precession set).

\section{STRATIGRAPHY OF SITE 801: JURASSIC THROUGH LOWER CRETACEOUS}

At Site 801 , located in the Pigafetta Basin of the western Central Pacific $\left(18.65^{\circ} \mathrm{N}, 156.35^{\circ} \mathrm{E}\right)$ (Fig. 1), we drilled the oldest sediments and basaltic basement of the Pacific Ocean Basin (Shipboard Scientific Party, 1990c). The Callovian (upper Middle Jurassic) through Valanginian (Lower Cretaceous) strata consist of a 144-m succession of brown to red, clayey radiolarites and radiolarian chert (Fig. 2). Age control is predominantly from radiolarian assemblages, but also includes a few diagnostic calcareous nannofossil assemblages. The original depositional setting of these radiolarites was in equatorial to low tropical latitudes. The high sedimentation rate of the radiolarites, ranging from 4 to $10 \mathrm{~m} / \mathrm{m} . \mathrm{y}$., and the oxidized nature of the sediments indicate that the Late Jurassic-Early Cretaceous equatorial Pacific Ocean had high surface productivity, presumably from upwelling of nutrients associated with the equatorial-divergence high-fertility zone, and possibly active circulation of well-ventilated bottom waters. The rarity of calcareous nannofossils may be caused by the dominance of radiolarians within the planktonic food chains of the near-equatorial high-fertility regions during the Jurassic (Jones and Murchey, 1986; Baumgartner, 1987).

Hole $801 \mathrm{~B}$ had extremely poor recovery of these Jurassic and Lower Cretaceous radiolarites due to the difficulty of coring interbedded clayrich radiolarite and brittle chert layers. The recovered pieces of radiolarites indicated small-scale $(5-20 \mathrm{~cm})$ variations in the abundances of radiolarians and clay and the related degree of silicification (Shipboard Scientific Party, 1990c). Such alternations were most apparent in the better-recovered Callovian red radiolarites. The variations in 


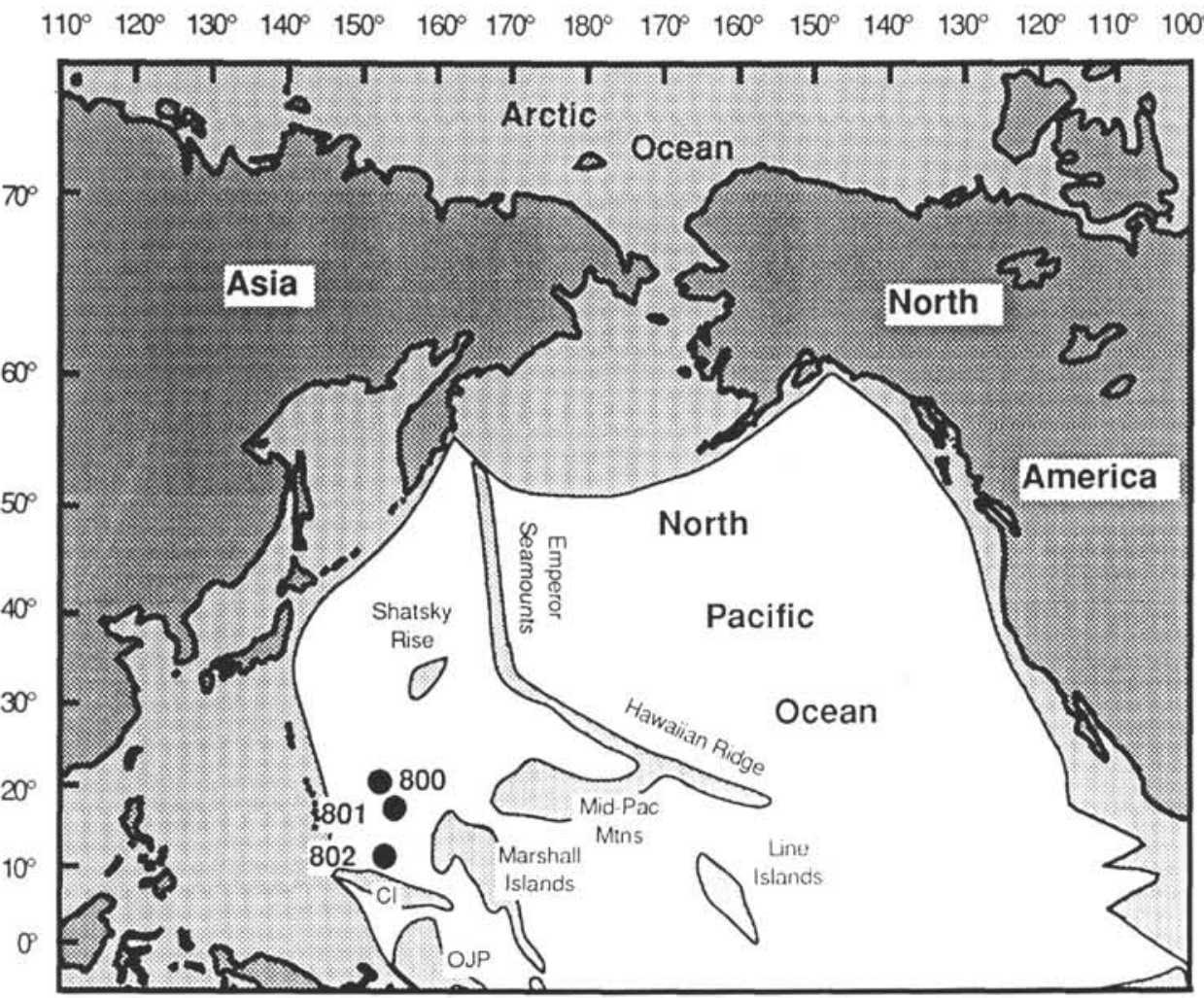

Figure 1. Locations of Leg 129 sites in the western Pacific Ocean. CI = Caroline Islands; OJP= Ontong Java Plateau.

radiolarian and clay abundance may reflect fluctuations in surface productivity, in influx of eolian dust and in bottom dissolution of silica-all these factors should be influenced by climatic-oceanographic cycles modulated at Milankovitch periodicities.

Core recovery was inadequate to document the cyclicity of radiolarian and clay abundances, but downhole logs, especially the gamma-ray intensity and Formation MicroScanner resistivity imagery, enabled analysis of the characteristics of the continuous in-situ sedimentary section. Application of three-dimensional spectral analysis to an overlapping set of 40-m windows from the gamma-ray intensity log enabled us to identify a suite of cycles consistent with the 95-123-413 k.y. eccentricity periods within the Jurassic through Lower Cretaceous radiolarite section of Site 801. The consistency of the ratios of these cycles to the eccentricity periods allowed the tuning of sedimentation rates throughout the section and the identification of major discontinuities in deposition at the Callovian-Oxfordian boundary and at the Tithonian-Berriasian boundary.

\section{Lithologic Units and Facies}

Shipboard subdivision of the Jurassic through Lower Cretaceous section into lithologic units and subunits was based upon the character of the recovered sediments (Fig. 2). The major facies shifts and corresponding lithologic subdivisions are supported by geochemical logging of the in-situ sediments and by Formation MicroScanner observations (Molinie and Ogg, this volume). Details of the lithostratigraphy and biostratigraphy of Site 801 are given by Shipboard Party (1990c), Ogg et al. (this volume), and Molinie and Ogg (this volume).

Lithologic Unit V (442.9-461.6 meters below seafloor, or mbsf), dated as Callovian to latest Bathonian, consists of red claystone alternating on a 5- to $10-\mathrm{cm}$ scale with radiolarite. The lower half of this unit consists of a series of slump deposits. This facies overlies oceanic crust of pillow basalts and sills interbedded with silicified claystone, metasediments, and deposits of hydrothermal origin.
Lithologic Subunit IVB (400.6-442.9 mbsf) of brown clayey radiolarite contains Oxfordian, Kimmeridgian, and Tithonian radiolarian assemblages and rare nannofossils. Chert or radiolarian porcellanite occurs mainly as lenses and is more common in the lower half of this subunit. There is a biostratigraphically defined hiatus at the Callovian-Oxfordian boundary (lithologic Unit IV/V boundary), in addition to the major facies change indicated by color, textural, and beddingdip differences. It is probable that much of the late Callovian and early Oxfordian is absent.

Lithologic Subunit IVA (318.3-400.6 mbsf), dated as Tithonian through Valanginian, is brown radiolarite with abundant dark brown chert. Subunit IVA has a generally lower clay content than the underlying Subunit IVB and displays indications of rhythmic banding of clay content, color darkness, radiolarian abundance, and/or degree of silicification at approximately 5 -cm intervals. Cores in the lower portion of Subunit IVA recovered only a few pieces of chert, and Formation MicroScanner resistivity imagery indicated that this interval (378-401 mbsf) consists almost entirely of banded chert (Molinie and Ogg, this volume). This Subunit IVA/B boundary is displayed in Formation MicroScanner imagery of Hole 801B as an upward transition from radiolarian claystone to bedded cherts as bands of chert become more abundant. A postulated mid-Tithonian hiatus, which was suggested by the Shipboard Scientific Party (1990c) based on the apparent downward increase in bedding dip and clay content, is largely an artifact of the poor recovery of the transition and is probably not present.

Lithologic Unit III (318.3-126.5 mbsf) consists of volcaniclastic turbidites with minor pelagic sediment intervals and is dated as Cenomanian to Albian with an undated post-Valanginian interval at the base. The contact between lithologic Units IV and III is displayed on the Formation MicroScanner imagery as a meter-thick, well-lithified horizon sharply in contrast to the overlying finely bedded clayrich turbidites and the underlying clayey radiolarite and probably 
represents a cemented hardground and interval of nondeposition (Molinie and $\mathrm{Ogg}$, this volume).

Downhole logging data indicates several distinctive facies shifts within and bounding lithologic Unit IV (Appendix; Molinie and Ogg, this volume). Our interpretation of the major facies shifts is summarized in Table 1.

During the Late Jurassic and Early Cretaceous, the site drifted slowly southward from a position in low latitudes into southern mid-latitudes (Sager, in press; Shipboard Scientific Party, 1990c; Steiner and Wallick, this volume). The abundance of chert in the Tithonian is probably due to an increased sedimentation rate of radiolarians during the proximity to the high-productivity paleoequator.

\section{Estimated Sedimentation Rates from Biostratigraphic Data}

Minimum average rates of sediment accumulation for each lithologic unit can be estimated by assuming continuous deposition completely spanned the geologic stages given by the biostratigraphy. The minimum accumulation rate of lithologic Unit IV, if the Oxfordian through Valanginian stages are completely present, is about $4 \mathrm{~m} / \mathrm{m}$.y. (123.6 $\mathrm{m}$ in $32 \mathrm{~m} . \mathrm{y}$.). The minimum accumulation rate of Unit $\mathrm{V}$, if the entire Callovian is present, is $3 \mathrm{~m} / \mathrm{m}$.y. ( $18 \mathrm{~m}$ in $6 \mathrm{~m} . \mathrm{y}$.). The actual rates of pelagic sedimentation are likely to be greater than these minimum average accumulation values, unless pulses of redeposition are common.

These accumulation rate computations have at least four sources of possible error: (1) the estimated thickness of the sedimentary unit spanning such ages, (2) the presence of hiatuses within the sedimentary unit, (3) the assignment and precision of biostratigraphic ages, and (4) the selected absolute geological time scale.

The shipboard lithologic unit boundaries are based entirely upon the level in the core recovery at which a major lithologic change is recorded. Core recovery was typically only $20 \mathrm{~cm}$ out of each $4.5-\mathrm{m}$ interval; therefore, these lithologic boundaries may actually be up to $4 \mathrm{~m}$ lower in the in-situ sedimentary section (to the base of the drilled core interval) or, considering that most boundaries were noted at the top of a core, could also be up to $4 \mathrm{~m}$ higher (within the previous drilled interval). These position inaccuracies also apply to biostratigraphic samples. The Callovian/Oxfordian boundary and probable unconformity at the top of lithologic Unit V, was placed at $442.9 \mathrm{mbsf}$, just below the top of Core 129-801B-33R, but it was suggested that the few pieces of clayey radiolarite recovered in Core 129-801B-32R may be downhole caving. Therefore, the Callovian-Oxfordian boundary hiatus falls somewhere in the interval of 434-445 mbsf. Formation MicroScanner imagery of Hole $801 \mathrm{~B}$ verified an unconformity at $439 \mathrm{mbsf}$ (Molinie and Ogg, this volume). The Subunit IVA/B boundary, placed at the top of Core 129-801B-24R or 400.6 mbsf, occurs somewhere in the interval of 396-404 mbsf, and Formation MicroScanner imagery places this change at 396 mbsf.

The facies change in Subunit IVA from bedded chert upward to clayey radiolarite at about Core $801 \mathrm{~B}-20 \mathrm{R}$ (374.5-383.5 mbsf) is displayed on Formation MicroScanner resistivity imagery as a very sharp boundary at about $378 \mathrm{mbsf}$ (Molinie and Ogg, this volume). This boundary also coincides with the radiolarian-defined zonal boundary between Tithonian and undifferentiated Berriasian-Valanginian. Therefore, this sudden facies change is possibly linked with an hiatus encompassing portions of the late Tithonian and Berriasian stages. The topmost portion of Unit IV does not extend to the Dibolachras tytthopora radiolarian zone of latest Valanginian (Shipboard Scientific Party, 1990a, 1990c), implying that this unit may not include any of the late Valanginian.

Lithologic Unit V, if spanning only the early Callovian or only 3 m.y., may have a sedimentation rate of $6 \mathrm{~m} / \mathrm{m}$.y. or greater. Subunit IVB, if spanning only the mid-Oxfordian through earliest Tithonian, hence accumulating $42.3 \mathrm{~m}$ in $10 \mathrm{~m} . \mathrm{y}$, may have a sedimentation rate of $4 \mathrm{~m} / \mathrm{m}$.y. Subunit IVA, if spanning the mid-Tithonian through
Table 1. Stratigraphy of lithologic Unit IV (clayey radiolarites of Upper Jurassic and Lower Cretaceous) from recovered sediments and logging interpretations.

\begin{tabular}{|c|c|}
\hline $\begin{array}{l}\text { Depth } \\
\text { (mbsf) }\end{array}$ & Lithologic boundary \\
\hline 315 & Probable top of Unit IV (from logs) \\
\hline 318.3 & Top of Unit IV (according to core recovery) \\
\hline 358 & Chert-rich overlying clay-rich interval \\
\hline 372 & Top of very clay-rich interval \\
\hline 379 & Top of banded chert (at $378 \mathrm{~m}$ in gamma log) \\
\hline 400.6 & Subunit IVA/IVB boundary (according to core recovery) \\
\hline 401 & Base of banded chert (at $400 \mathrm{~m}$ in gamma log)/Top of clay-rich interval \\
\hline 413 & Clay-rich, changing downward to more silica \\
\hline 440 & Top of Unit V (sudden downward drop in silica log) \\
\hline 442.9 & Top of Unit V (according to core recovery) \\
\hline
\end{tabular}

mid-Valanginian, an accumulation of $82.3 \mathrm{~m}$ in $15 \mathrm{~m} . \mathrm{y}$, may have a sedimentation rate of $7 \mathrm{~m} / \mathrm{m}$.y., and possibly much higher if much of the latest Tithonian and early Berriasian is absent. The chert-rich Tithonian portion of Subunit IVA (Cores 129-801B-20R through $-23 \mathrm{R}$, or $26.1 \mathrm{~m}$ in perhaps $4 \mathrm{~m} . \mathrm{y}$.) may have a sedimentation rate on the order of $6 \mathrm{~m} / \mathrm{m} . \mathrm{y}$.

Biostratigraphy for the Jurassic through Lower Cretaceous of Site 801 is primarily from radiolarian assemblages correlated with the radiolarian zonation for Japanese radiolarites of Matsuoka and Yao (1985, 1986) with minor modifications (Shipboard Scientific Party, 1990a, 1990c). Geologic age assignments depend largely on the correlation of Matsuoka and Yao's (1985) zonation with Baumgartner's $(1984,1987)$ zonation for the Tethyan-Atlantic region. In general, the radiolarian zonation allows resolution only to the stage level (e.g., "Tithonian" but not "early Tithonian"). A few nannofossils were observed which were consistent with the radiolarian zones and, in one instance, allowed improved resolution ("middle Tithonian" assigned to the base of Core 129-801B-25R, hence within the interval spanning 398 to $414 \mathrm{mbsf}$ ). These broad biostratigraphic ages imply an uncertainty of approximately a half-stage, or approximately 3 m.y., on the date of any particular horizon.

Accumulation rates were computed using the Decade of North American Geology geological time scale (Kent and Gradstein, 1985; Palmer, 1983) which derived Late Jurassic-Early Cretaceous stage boundaries from magnetostratigraphic correlations and from the assumption of constant spreading rates on the Hawaiian set of Pacific magnetic anomalies. If spreading rates on this ridge varied during the Late Jurassic or Early Cretaceous, then individual stages could be significantly shorter or longer in duration. For example, the Kent and Gradstein (1985) scale assigns a duration of 6 m.y. to the Berriasian stage; in contrast, a eccentricity-cycle analysis of upper Berriasian sediments in Spain suggested that the entire Berriasian stage may span only 3.2 to 3.9 m.y. (ten Kate and Sprenger, 1989).

We will return to the implications of the preceding estimates of accumulation rates with the sedimentation rates computed from analysis of Milankovitch cycles in a later section.

\section{LOGGING DATA AND RESOLUTION}

A suite of logging runs were made of the Jurassic through midCretaceous section of Hole 801B (Shipboard Scientific Party, 1990c). The geochemical logs verified the shipboard sedimentological observations of long-term $(10-100 \mathrm{~m})$ variations in the character of the radiolarites, especially in average clay content and silicification (see Appendix). In addition, the logging signals displayed fluctuations in composition and silicification at the scale of 1 to $10 \mathrm{~m}$.

The ability to detect Milankovitch cycles within logging data depends on the resolution of the tool and spacing of measurements relative to the sedimentation rate- to detect cyclicity using Fourier analysis of such signals requires at least two points per cycle. There- 


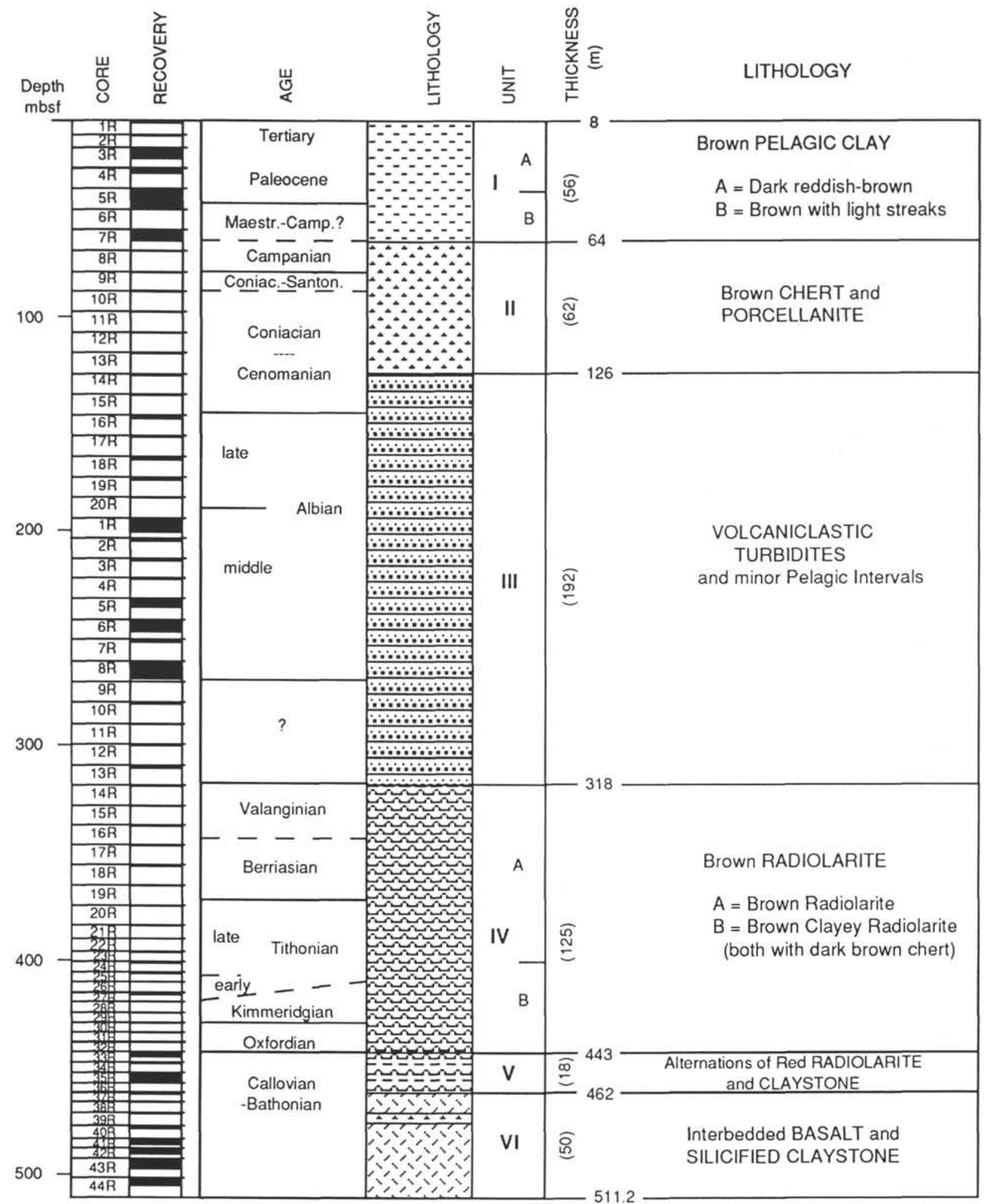

Figure 2. Stratigraphy of Holes 801A and 801B.

fore, a resistivity-log signal having a 1-m resolution (Schlumberger, 1987) requires a sedimentation rate of at least $20 \mathrm{~m} / \mathrm{m}$.y. to detect the suite of eccentricity cycles ( 95 k.y., 123 k.y., 413 k.y.) or at least $100 \mathrm{~m} / \mathrm{m}$.y. to detect precession cycles ( 23 k.y., 19 k.y.). The natural gamma-ray intensity logging tool has a resolution of $0.3 \mathrm{~m}$ (Schlumberger, 1987) and can detect these eccentricity cycles if the sedimen- tation rate is greater than $6 \mathrm{~m} / \mathrm{m} . \mathrm{y}$. Most geochemical logging tools have a resolution of $0.6 \mathrm{~m}$. The Formation MicroScanner, having a resolution down to $1 \mathrm{~mm}$, should provide the ultimate cycle-detection logging tool. The effective resolution of those logs, which record measurements at intervals more closely spaced than the resolution of the tools, can theoretically be improved if the signal is deconvolved 
using the response function of the tool. For example, resistivity tool measurements were made at $15-\mathrm{cm}$ spacing in Hole 801B; therefore, a deconvolved signal should enable resolution of cycles with wavelengths of $30 \mathrm{~cm}$ or greater.

Geophysical and geochemical logs of ODP holes have been used to identify periodic lithologic changes corresponding to Milankovitch climatic-oceanographic cycles. Jarrard and Arthur (1989) applied spectral analysis to sonic, resistivity and U/Th logs of Pleistocene sediments at ODP Sites 645 and 646 in the Labrador Sea and Baffin Bay. Periodicities in porosity of 20 k.y., 40 k.y., and 100 k.y. were interpreted by them as variations in clay content and grain-size sorting induced by bottom-water currents fluctuating in response to Milankovitch cycles. Geochemical logging at ODP Site 704 on Meteor Rise detected obliquity and possibly eccentricity cycles in amplitude spectra of calcium and silica (Mwenifumbo and Blangy, 1991; Nobes et al., 1991). Obliquity and eccentricity cycles were also observed in gamma-ray, resistivity, and sonic logs of upper Tertiary sediments at ODP Site 693 on the Antarctic continental margin (Golovchenko et al., 1990), and obliquity influences on Pliocene-Pleistocene eolian dust influx to the Sea of Japan were deduced from natural gamma-ray logs at ODP Site 798 (Demenocal and Bristow, 1990).

We applied spectral analysis to the intensity fluctuations of natural gamma-ray emission recorded at $15-\mathrm{cm}$ intervals during logging of the Jurassic and Lower Cretaceous section at Site 801. The natural gamma-ray $\log$ is a measurement of the natural radioactivity of formations and is especially responsive to the amount of clay or shale, which tend to concentrate the radioactive elements (Schlumberger, 1987). In sedimentary formations, the vertical resolution of the gamma-ray $\log$ is about $30 \mathrm{~cm}$. Therefore, the required minimum sedimentation rate for resolution of eccentricity cycles is about $6 \mathrm{~m} / \mathrm{m}$.y., of obliquity cycles is $15 \mathrm{~m} / \mathrm{m}$.y., and of precession cycles is $30 \mathrm{~m} / \mathrm{m} . \mathrm{y}$. However, the $15-\mathrm{cm}$ spacing of gamma-ray emission measurements implies that there is a succession of overlapping $30-\mathrm{cm}$ windows, therefore we estimate that the effective resolution of cycle wavelengths is approximately $45 \mathrm{~cm}$ or greater. Using this resolution estimate, an sedimentation rate of $6 \mathrm{~m} / \mathrm{m}$.y. for the Upper JurassicLower Cretaceous of Site 801 would enable identification of cycles having periods of $80 \mathrm{k} . \mathrm{y}$. or longer. Therefore, eccentricity cycles can be analyzed, but obliquity and precession cycles cannot be detected except in intervals of rapid sedimentation.

\section{SPECTRAL ANALYSIS METHODS}

In this study, we first performed a frequency analysis of the entire lithologic Unit IV interval and observed the presence of major broad peaks. The ratio of the dominant peaks are consistent with the major eccentricity periods. We then applied spectra analysis to an overlapping series of close-spaced sliding windows to resolve the complete spectra of these possible eccentricity cycles and to identify the shifting of peaks caused by variations in mean sedimentation rates.

Sedimentation rates are rarely constant over multimillion-year intervals, therefore the spatial wavelengths of periodic sedimentary cycles will shift. However, if those cycles are reflections of Milankovitch orbital cycles, then the relative ratios within the suite of those wavelengths will remain constant. If spectral analysis were applied to the entire depth-series signal from such a situation, the result would be either broad-band peaks or inconclusive cyclicity. However, if subsets ("windows") of this depth signal were analyzed, the individual results might display well-defined cyclicity, but there would be a consistent relative displacement of the wavelengths of peaks between windows. Such displacements would be an indication of changing sedimentation rates, provided the ratios within the suite of peak wavelengths remain constant.

This sliding-window comparison of spectral peak ratios is also a valuable supplemental technique to demonstrate the presence of Milankovitch cyclicity. If the windows yield shifting peaks which do not retain a constant ratio, then it is possible that the cyclicity may be due to non-Milankovitch-related variations, such as diagenetic segregation, turbidite frequency, or other sedimentary phenomena.

Window size is adjusted according to the approximate spacing of the longest period cycles of interest and to the stability of sedimentation. A smaller window is more accurate for determining sedimentation rate variations, but will have poorer resolution of longer period cycles. Use of narrow windows can also result in aliasing of spectra; a problem which can be partially reduced by application of multiple window tapers (e.g., Thomson, 1982).

Our procedure can be summarized as follows: A high-pass and a low-pass filter are applied to the signal to remove long-period trends and high-frequency noise. A "window taper" is applied to eliminate discontinuities across the ends of the signal interval. The Fourier transform of this processed signal is displayed as a spectral plot of the amplitude of different frequency components.

\section{Signal Filtering and Processing}

In order to obtain a time-series analysis of the natural gamma-ray logging signal, we normalized the data set to assure numerical stability in the calculation. The normalization procedure removes the dominating zero-order term, associated with the non-zero mean of the $\log$ data, that would otherwise be present in the amplitude spectrum.

As with any spectral analysis technique, care must be taken in order to achieve reliable results (e.g., Kanasewich, 1981). One problem is that the raw data suffer from noise of very high frequency and high energy. First, but only for the initial analysis of the entire interval, we applied a high-pass filter with a cut-off frequency of 0.15 cycles $/ \mathrm{m}$, which eliminates long-period cycles longer than about $7 \mathrm{~m}$. These cycles, corresponding to periods longer than $700 \mathrm{k} . \mathrm{y}$. at an average sedimentation rate of $10 \mathrm{~m} / \mathrm{m}$.y., were omitted because they would diminish the energy of the other frequencies. However, in the case of sliding windows, a high-pass filter was not required because the window itself cuts off very long-period cycles and we desired to interpret the remaining low-frequency peaks, as will be explained later.

Second, the highest frequency of interest for the analyses of both the whole interval and the sliding windows was chosen as $1.5 \mathrm{cy}-$ cles $/ \mathrm{m}$, corresponding to cycles with wavelengths less than $70 \mathrm{~cm}$, or equivalent to less than 70 k.y. periods at a sedimentation rate of $10 \mathrm{~m} / \mathrm{m}$.y. This low-pass filter, which removes all high-frequency noise and signal, was chosen to avoid problems from aliasing caused by the Nyquist frequency. However, this filter would also eliminate $100-\mathrm{k} . \mathrm{y}$. period if the sedimentation rate is $7 \mathrm{~m} / \mathrm{m} . \mathrm{y}$. or slower. The gamma-ray measurements were made at every $0.15 \mathrm{~m}$ (actually, at 6-in. spacing); therefore, the corresponding Nyquist frequency is $3.28 \mathrm{cycles} / \mathrm{m}$. Thus, the low-pass cut-off frequency of $1.5 \mathrm{cy}$ cles/meter, which is equivalent to the Nyquist frequency divided by two, should avoid the main signals caused by aliasing. Harmonics of the Nyquist frequency may still be present as multiples of 3.28 cycles $/ \mathrm{m}$, but these will have reduced amplitudes.

Another problem that must be taken into account in the case of narrow windows is biasing of spectra by the windowing effect. Our selection of a 40-m sliding window corresponds to about 260 data points. The common procedure to reduce this problem is to apply a window taper, such as a Tukey Hanning or split cosine bell, before performing the Fourier transform. Multiplying the truncated log by such a taper will eliminate the discontinuities across the ends of the window, thereby diminishing leakage. On the other hand, frequencies resistant to spectral leakage tapers weight the truncated log unequally. The multi-taper spectral analysis method (Thomson, 1982) used to calculate spectra at each selected depth window allows reduction of spectral leakage, and, at the same time, does not discard data in the chosen window. This method is based on the use of several leakage resistant tapers. We used a combination of five tapers. Each taper was separately applied to the log interval before calculating spectra by using the Fourier transform of each tapered log. The combination 


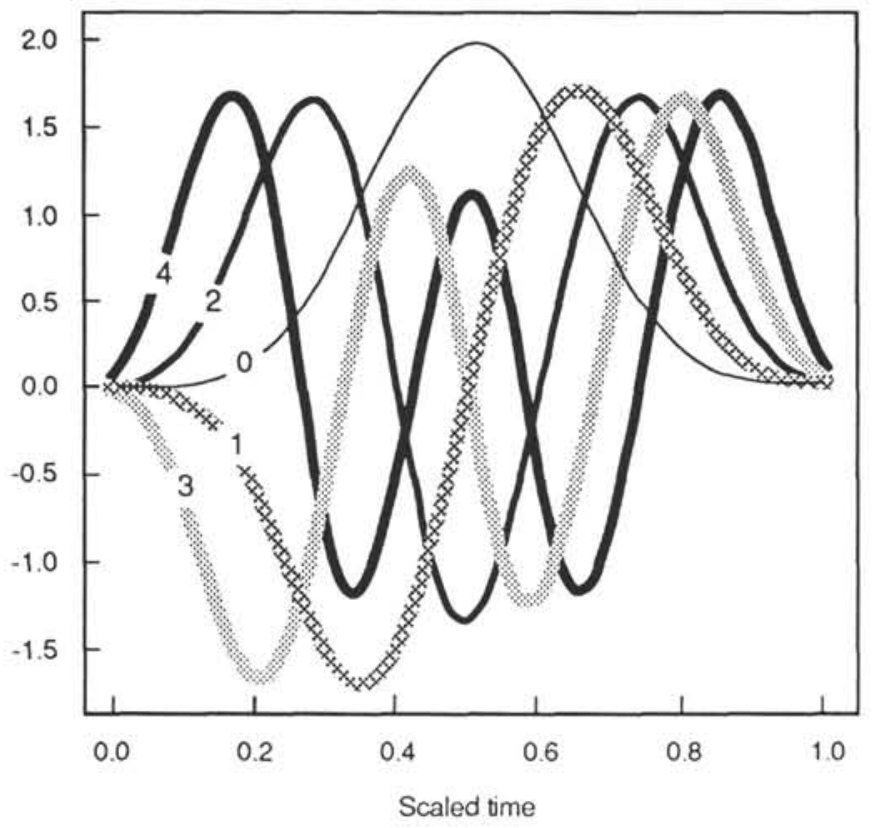

$4 \pi$-prolate tapers

Figure 3. Example of the five lowest-order window tapers applied to the gamma-ray signal before performing the Fourier transform. In the case of narrow windows, application of these tapers reduces the windowing effect.

of these eigen-spectra yields our single spectral estimate for the selected depth window. By using several tapers of different shape, the information discarded by the first taper is partially recovered by the second one, and the data discarded by the first two tapers is partially recovered by the third and higher order tapers (Fig. 3). This technique is especially useful in the case of small windows, such as those in our case.

\section{Spectral Analysis of Entire Unit}

The entire data set of lithologic Unit IV was initially analyzed as a single window. The spectral analysis yields an abundance of spectral peaks (Fig. 4). The dominant long-period peak has a wavelength of $4.18 \mathrm{~m}$, and the dominant short-period peak has a wavelength of $1.08 \mathrm{~m}$. At a sedimentation rate of $10 \mathrm{~m} / \mathrm{m}$.y., a typical value for biogenic pelagic sedimentation in the modern ocean, these two peaks would correspond to periods of 418 k.y. and 108 k.y. These "first-guess" cycles are similar to the eccentricity periods of 413 k.y. and of combined 95 k.y. and 123 k.y. If the long-period peak is set to 413 k.y., the mean sedimentation rate of $10.1 \mathrm{~m} / \mathrm{m}$.y. would tune the other peak to $107 \mathrm{k.y}$. (Fig. 4). In addition to these two dominant peaks, the abundance of adjacent lesser peaks suggests that sedimentation rates, hence wavelengths of cycles, may vary throughout this interval and that other cyclic frequencies and harmonics may be present. The coincidence of the ratio of the dominant long-period and short-period peaks to the ratio of the two major eccentricity cycles encouraged us to proceed with a detailed sliding-window ("three-dimensional") spectral analysis through the interval of lithologic Unit IV.

\section{3-D Spectral Analysis Results}

For calculation of the three-dimensional spectrogram, a sliding $40-\mathrm{m}$ window was moved at regular $1.0-\mathrm{m}$ intervals throughout the normalized or de-meaned log signal, and the multi-taper spectral technique was applied to each of these intervals. To a first approximation, the spectral characteristics obtained by Fourier analysis of this window can be considered as representative of the depth in the middle of the interval. However, as will be noted below, some adjustments must be applied if there is a major discontinuity or acceleration in sedimentation rate occurring within the windowed interval. The resulting three factors of cycle wavelength (expressed as cycles/meter) vs. spectral power vs. depth may be represented either as a 3-D plot (Fig. 5), as a color-coded image called a spectrogram (e.g., cover figure in Molinie and Ogg, 1990), or as a set of selected power spectra (Fig. 6).

The upper sediments of lithologic Subunit IVA (365-380 mbsf) display a dominant long-period and short-period peak in all windows (Figs. 5 and 6). If the major low-period peak at about $0.2 \mathrm{cycles} / \mathrm{m}$ (5-m wavelength) is assigned as 413 k.y., then the corresponding "tuned" periods of the short-period peak matches the expected 95-k.y. eccentricity cycle (Table 2 ). A distinct peak near 0.6 cycles $/ \mathrm{m}$ (1.7-m wavelength) corresponds closely to the 123-k.y. eccentricity cycle (Fig. 6, Table 2). The fact that these three peaks are consistently present with the proper ratios in each of the deeper windows, despite apparent changes in sedimentation rates, supports our interpretation that the corresponding eccentricity cycles are an important factor within the sedimentary record. These three peaks were traced downward from their most pronounced expression at $346.9 \mathrm{mbsf}$ to more subdued appearances in the lower portion of the lithologic unit.

Passing downward from about 370 to $390 \mathrm{mbsf}$, one set of peaks diminishes as another set appears, grows in intensity, and eventually becomes dominant. This progressive replacement of spectral peaks causes difficulties in identifying the "dominant" short-period cycles within this interval; therefore, the assignment of the " $123 \mathrm{k.y."}$. and "95 k.y." peaks was partially based upon the ratios to the distinct "413 k.y" peak (Table 2). Below 410 mbsf, the short-period peaks are more distinct.

A sharp change in sedimentation rate will result in the replacement of one set of peaks by another set, which have different wavelengths but retain the same ratio among those wavelengths. A different sedimentation rate, hence a new set of wavelengths for the cycles, will progressively occupy a greater proportion of the succession of $40-\mathrm{m}$ windows, thereby resulting in the progressive appearance of a new set of peaks. The level at which a discontinuity or rapid change in sedimentation occurs can be approximated from the depth of the window in which the amplitudes of the "underlying" and the "overlying" sets of peaks are nearly equal, as will be demonstrated later. Therefore, the replacement of peaks between 370 and 390 mbsf is interpreted as a discontinuity in sedimentation rate. In contrast, had there been a gradual change in sedimentation rate over a broad transition zone, then the cycle peaks would be expected to broaden or blur as their means shifted.

Cycles having periods significantly longer than " 413 k.y." are not readily apparent in our spectral analysis due to several factors including the window cutoff, the de-meaning signal processing and the dominance of the 413-k.y. peak. A peak corresponding to approximately 800 k.y. is present in the spectra of the lower portion of lithologic Unit IV, which has a low sedimentation rate, but this may be a harmonic of the " $413 \mathrm{k} . \mathrm{y}$." frequency rather than an actual long-period cycle.

The lowest set of windows ( $390-420 \mathrm{mbsf}$ ) displays a subdued spectra with less visually dramatic peaks. Our identification of traceable peaks among these windows have ratios of wavelengths corresponding nearly exactly to those expected from the eccentricity cycle set of 413-123-95 k.y. (Table 2). This continued close correspondence of the ratios supports the interpretation that the new set of peaks represents the same relative cycle periods, that have been uniformly shifted in wavelength due to a higher sedimentation rate.

The lowest spectral analysis windows (e.g., 428.4 mbsf window in Fig. 7) display a prominent widened long-period peak, which we assigned to the 413 k.y. eccentricity cycle. Short-period cycles, if present, are very subdued within these lower windows.

\section{Computation of Sedimentation Rates and Discontinuities}

Within a given window, the wavelengths of the assigned eccentricity cycles enable computation of the mean sedimentation rate. In 

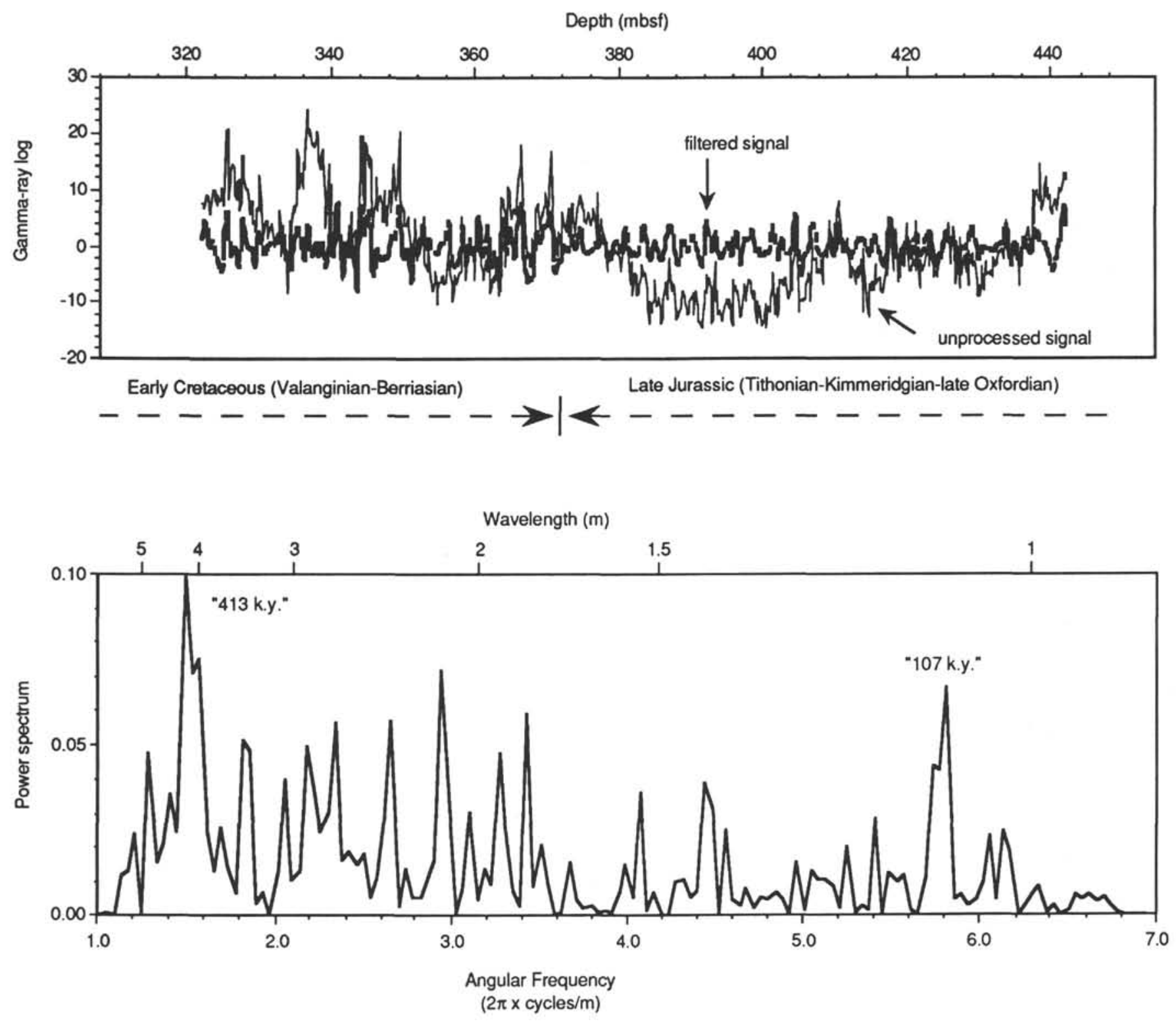

Figure 4. Comparison of filtered vs. unprocessed signals of the natural gamma-ray intensity log (relative intensities) spanning the entire lithologic Unit IV interval of Hole $801 \mathrm{~B}$, and the corresponding computed power spectra of the filtered gamma-ray signal. An average sedimentation rate of $10 \mathrm{~m} / \mathrm{m}$.y. would imply that the dominant long-period and short-period spectral peaks have periods of $408 \mathrm{k} . \mathrm{y}$. and $108 \mathrm{k} . \mathrm{y}$. These assignments are consistent with Milankovitch eccentricity periods of 413 k.y. and of combined 95 k.y. and 123 k.y. An assignment of 413 k.y. to the long-period peak implies an average sedimentation rate of $10.1 \mathrm{~m} / \mathrm{m} . \mathrm{y}$. and assigns a period of $107 \mathrm{k} . \mathrm{y}$. to the other peak.

a few of the windows where the identification of short-period cycles is ambiguous, the sedimentation rate (and corresponding assignment of short-period cycle peaks) is computed primarily from the assignment of the major long-period peak to the 413-k.y. eccentricity cycle. Implicit in this procedure is the assumption that the major spectral peaks are due to Milankovitch eccentricity cycles; an assumption supported by the ratio among long-period and short-period cycles remaining identical to the ratio expected from Milankovitch cycles (Table 2). Park and Herbert (1987) also concluded, from a similar procedure, that these three major eccentricity cycles, which they assigned as "400 k.y., 97.0 k.y., and 127.6 k.y.," played a major role in modulating pelagic deposition within a Albian core and enabled tuning of sedimentation rates.

As sedimentation rates gradually change, the location of spectral peaks shift, but the relative ratios within the suite must remain constant. The replacement of one set of peaks by another set having different wavelengths, but retaining the same ratios among their wavelengths, indicates a probable discontinuity in sedimentation rate.

The sedimentation rates computed according to the periodicity of the set of three cycles display a dramatic increase upward in average sedimentation rate from about $8 \mathrm{~m} / \mathrm{m}$.y. to $12-13 \mathrm{~m} / \mathrm{m}$.y. at about the 381 mbsf window-center level (Fig. 7). A less well-documented apparent decrease upward in sedimentation rate from $15 \mathrm{~m} / \mathrm{m}$.y. to $7-8 \mathrm{~m} / \mathrm{m}$.y. occurs at about the $420 \mathrm{mbsf}$ window-center level. These levels of rapid change are the center of the window in which the amplitude of the "old" and "replacement" set of peaks are nearly equal.

However, the actual depth at which the discontinuity in sedimentation occurs within these windows of "equal peak heights" would not be located at the center of the window. Suppose, to a first approximation, 


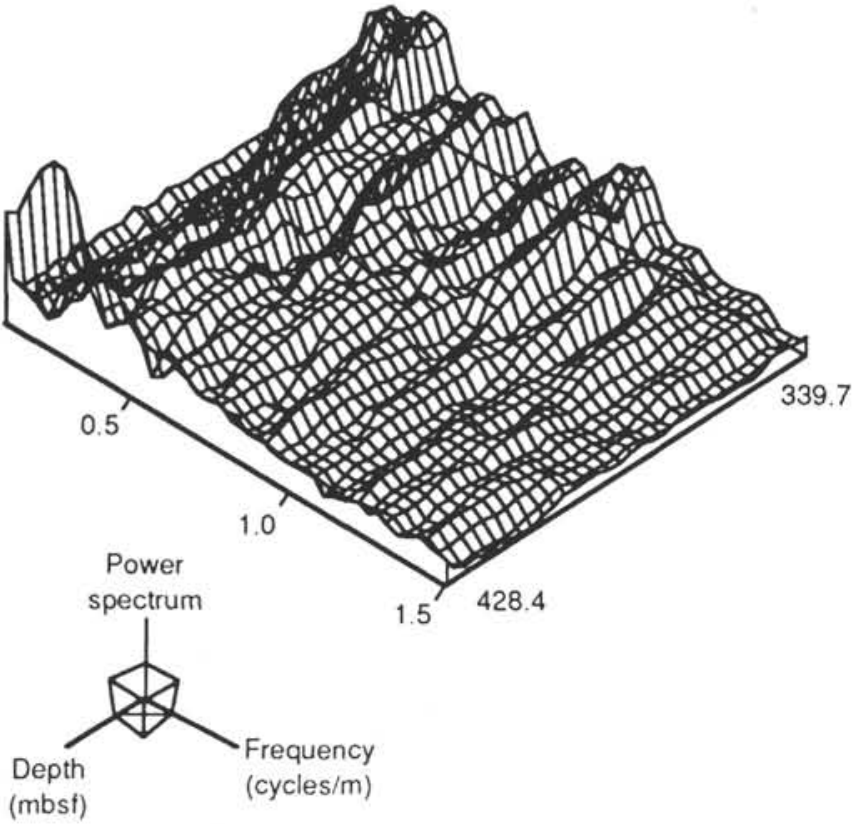

Figure 5. Three-dimensional plot of the power spectra vs. depth in Hole 801B for a series of close-spaced (3.0-m increments), overlapping sliding windows of $40-\mathrm{m}$ width. A subset of these power spectra at $9.0-\mathrm{m}$ increments is shown in Figure 6.

the height of a spectral peak reflects the number of corresponding cycles present within the window. This height-to-number relationship assumes that the amplitude of the cycle character remains constant. Then, the window in which the two sets of peaks have equal height is that interval where there is the same number of cycles of each set. Therefore, this window will also contain equal time spans above and below the discontinuity in sedimentation rates.

Consider the case of a $40-\mathrm{m}$ window having relatively rapid sedimentation (SedRate ${ }_{1}$ ) in the upper portion and a sharp discontinuity to much slower sedimentation (SedRate ${ }_{2}$ ) in the lower portion. In this example, a fixed-period cycle will have fewer occurrences per meter within the upper portion of the window where the cycle has a longer wavelength, than within the lower portion. The window in which the cycle displays two shifted and equal-height spectral peaks must represent the interval containing the same number of such cycles, hence correspondingly equal amounts of time, both above and below the discontinuity in sedimentation rate. Therefore, the level where the discontinuity in sedimentation rate occurs within this window is not at the middle of the window, but must be shifted in the direction of the slower sedimentation rate where the wavelengths for that cycle are shorter. The level of the discontinuity is where the number of wide-spaced cycles within the window (corresponding to thickness "Dist," of faster sedimentation) would be equal to the number of close-spaced cycles (corresponding to thickness "Dist ${ }_{2}$ " of slower sedimentation rate). Therefore, one finds the solutions to Dist, and Dist $_{2}$ in the two simultaneous equations:

$$
\text { Dist }_{1}+\text { Dist }_{2}=40 \mathrm{~m}
$$

[sum of thicknesses must equal the window size], and

$$
\left(\text { Dist }_{1} / \text { SedRate }_{1}\right)=\left(\text { Dist }_{2} / \text { SedRate }_{2}\right)
$$

[there is equal time above and below the discontinuity],

where the SedRates are calculated from the wavelength of the peak sets.
Solving the above equations for the 381-mbsf window-center, with a shift in sedimentation rate from about $8 \mathrm{~m} / \mathrm{m}$.y. upward to $11 \mathrm{~m} / \mathrm{m}$.y., implies that the actual change in sedimentation would be about $4 \mathrm{~m}$ lower within this $40-\mathrm{m}$ window, or at the level of $385 \mathrm{mbsf}$.

Similarly, for the 420-mbsf window-center, the actual shift from sedimentation rates of $14.2 \mathrm{~m} / \mathrm{m}$.y. upward to $6.3 \mathrm{~m} / \mathrm{m}$.y. would be about $8 \mathrm{~m}$ higher, or at the level of $412 \mathrm{mbsf}$. These calculations assume a sudden change in sedimentation rates, with relatively constant but different rates before and after the discontinuity - an assumption consistent with the plot of "tuned" sedimentation rates (Fig. 8).

\section{PHYSICAL REALITY OF CYCLES AND SEDIMENTATION RATES}

These computations of the sedimentation rates depend on two major assumptions. First, the spectral analysis peaks reflect actual cyclicity in the sedimentary record. Second, these cycles correspond to Milankovitch periods of eccentricity variations. To test these two assumptions, we (1) examine various alternative pseudo-cyclic sources or artifacts in the spectral analysis procedure, (2) compare a 40-m window of gamma-ray intensity measurements directly with the generated spectral peaks for that window to test if the cycles are apparent in the original logging signal, (3) match the individual gamma-ray peaks and corresponding cycles from this $40-\mathrm{m}$ window to sedimentary features observed in the high-resolution relative resistivity imagery provided by the Schlumberger Formation MicroScanner in order to determine the sedimentary cause of the cyclicity in the gamma-ray logging signal, and (4) compare the sedimentation rates and discontinuities calculated from the spectral analysis technique with the observed stratigraphy of Site 801 . These four approaches of analyzing for possible artifacts and comparing with other stratigraphic data provide some constraints on the reality of the computed eccentricity cycles. The ideal ground-truth procedure would be to compare the spectral analysis results directly against the sediments; however, coring of the Jurassic through Lower Cretaceous strata did not recover any intact interval thicker than approximately $25 \mathrm{~cm}$. Thus, only vague indications of possible precession-frequency alternations could be observed (Ogg et al., this volume). We must therefore rely on this set of indirect observations to verify the consistency of possible cycle wavelengths.

\section{Possible Sources of Artifacts in Spectral Analysis of the Gamma-ray Log}

\section{Errors in Logging Depths}

The apparent continuity in sedimentation rate across a distinct lithologic change (Subunit IVA/B boundary) and the discontinuities in sedimentation occurring within shipboard-defined lithologic units led to a thorough check of the calibration of logging depths to core depths. The conversion of the logging "feet below rig floor" depths into ODP's "meters below seafloor" was checked by comparing distinctive logging features to core recovery. The $40-\mathrm{m}$ width and $1.0-\mathrm{m}$ progressive offset of successive windows were also verified by matching individual peaks in gamma-ray intensity against the independent Formation MicroScanner imagery.

\section{Eccentricity Cycle Interpretation}

In sediments influenced by Milankovitch cycles, apparent peaks with 100-k.y. and 400-k.y. periods could also be artifacts of cycles caused by precession having periodicity of 23 k.y. and 19 k.y. if the wavelength of such precession effects is equal the spacing of measurements. Pisias and Mix (1988) suggested that a similar precessioninduced sampling bias of some oceanic cores yielded spurious results. This type of artifact requires that the $15-\mathrm{cm}$ spacing of gamma-ray logging measurements correspond to about 20 k.y., implying a sedimentation rate of $7.5 \mathrm{~m} / \mathrm{m} . \mathrm{y}$. or harmonics. Indeed, this sedimen- 


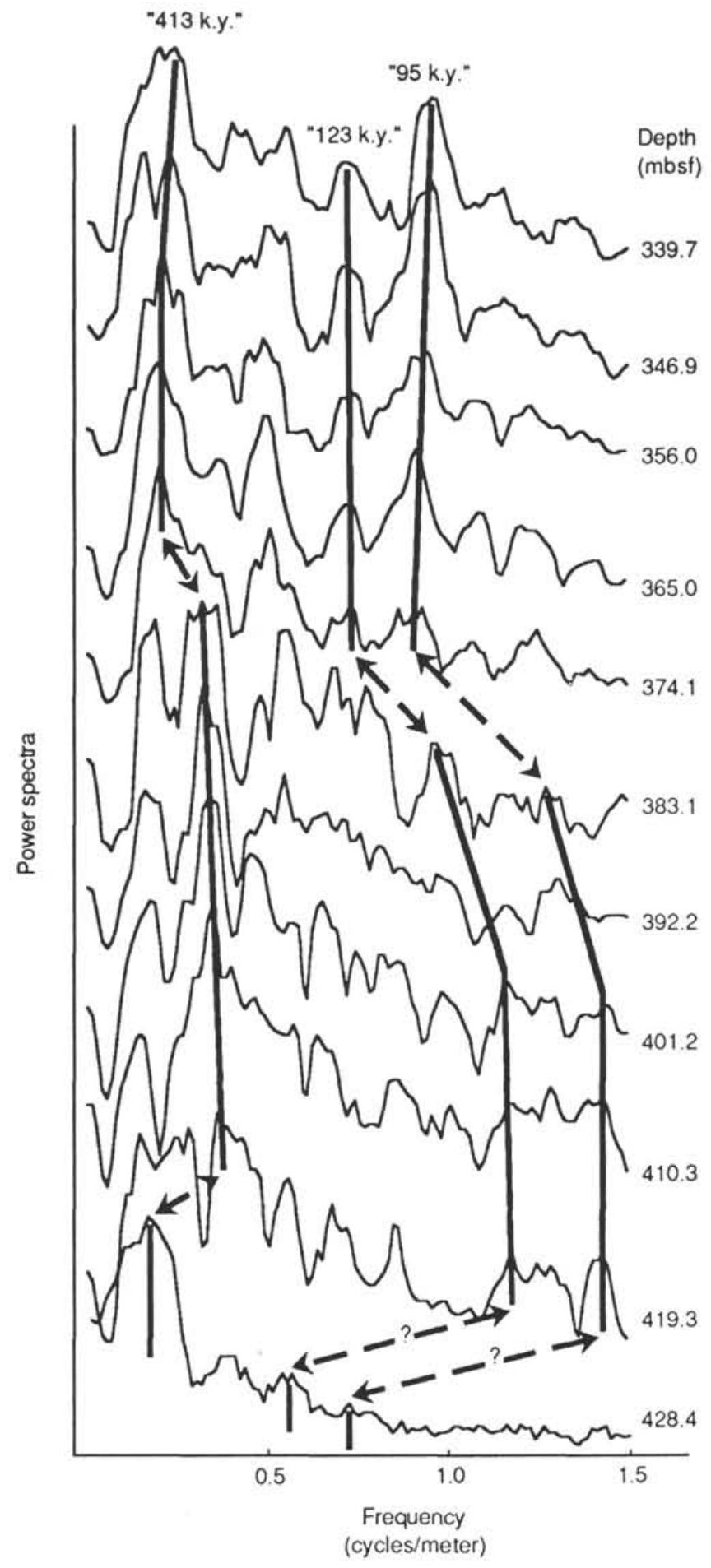

Figure 6. Power spectra of a series of overlapping 40-m width depth windows at 9- $\mathrm{m}$ increments through the Upper Jurassic-Lower Cretaceous radiolarites of Hole 801B with assignment of the three cycles induced by Milankovitch eccentricity periods. Assignments of short-period peaks " 123 k.y." and "95 k.y." are based partially upon a high-resolution 3-D spectrograph (see text) and partially upon the relative frequency ratio to the dominant long-period " 413 k.y." peak (Table 2). Trends and rapid changes or discontinuities in sedimentation rates result in shifting of the assigned cycle periods with depth (e.g., Fig. 7). tation rate is within the range of rates estimated for lithologic Unit IV. A distinct peak occurring on several of the traces could correspond to the "200-k.y." peak predicted by this sampling artifact; however, this "200-k.y." peak could also be the harmonic of the 95- and 123-k.y. peaks. The separation of the 95- and 123-k.y. peaks is not a completely reliable test, since the $123 / 95$ ratio is very similar to the $23 / 19$ ratio of the two precession frequencies (1.29 vs. 1.21). The main argument against a precession-induced sampling bias is that the observed drift of the peaks occurs independently of the constant spacing of gammaray measurements and can best be interpreted as gradual changes in sedimentation rate. This observed shifting of spectral peaks indicates that precessional aliasing is probably not important.

\section{Regular Heave of Ship}

The "95- and 123-k.y." cyclicity could be due to periodic heaving of the logging string in response to two dominant periods in the surface swells. Before correction for acceleration, the Formation MicroScanner trace displayed jerks of up to $0.5 \mathrm{~m}$, presumably followed by stillstands, which had an average spacing of one meter. The gamma-ray log would be subject to the same wave-heave problems, resulting in duplicate measurements and half-meter gaps occurring at about $1-\mathrm{m}$ intervals. The magnitude of this effect depends on the efficiency of the heave-compensator on the drilling derrick. This $1-\mathrm{m}$ wavelength corresponds approximately to the wavelength of the "95-123 k.y. cycles" expected for a $12 \mathrm{~m} / \mathrm{m}$.y. sedimentation rate. Therefore, it is necessary to independently verify that the sedimentary record indeed contains clay-enrichment or silica-enrichment features at approximately $1-\mathrm{m}$ intervals.

\section{Nyquist Harmonics}

The cycles could be harmonics of the Nyquist sample frequency. The 15.2-cm spacing of measurement would result in harmonics at $91 \mathrm{~cm}, 106 \mathrm{~cm}$, etc. At a sedimentation rate of $11 \mathrm{~m} / \mathrm{m}$.y., these artifacts would be interpreted as cycle periods of 100 k.y. and 122 k.y. This phenomenon seems to be unimportant considering the absence of noticeable higher harmonics, the drift of the peaks through the units and the dominance of the 400-k.y. peak.

The best test for the presence of these and other artifacts in the spectral analysis is whether the " $400-k . y . "$ and " $100-k . y . "$ cyclicity are visually or physically apparent in the core recovery or in the independent logging runs by the high-resolution Formation MicroScanner. If the cycles are physically present and if the ratios are similar to ratios of Milankovitch cycles, then it is possible that these Milankovitch climatic-oceanographic cycles played a role in the sedimentation.

\section{Spectral Cyclicity of a 40-m Window Compared with Gamma-ray Logging Measurements}

For the first comparison of the "black-box" approach of filtering and time-series analysis of the logging signals to the physical record of the sediments, we selected a $40-\mathrm{m}$ window centered at 365 mbsf. The cycle frequencies from this 40 -m interval were directly matched to (1) the gamma-ray signal and (2) the corresponding detailed Formation MicroScanner imagery of the sediments. Spectral analysis of this $40 \mathrm{~m}$ interval displays a major distinct peak, which we assigned as a possible "413-k.y." eccentricity cycle (Fig. 6). This cycle should be apparent in both the gamma-ray signal and the Formation MicroScanner imagery.

The gamma-ray signal from 345 to 385 mbsf, corresponding to the spectral analysis of the $40-\mathrm{m}$ window centered at $365 \mathrm{mbsf}$, was displayed as gamma-ray intensity vs. depth (Fig. 9). This signal has been processed by "removing the mean" and by applying filters of 0.1 and $1.5 \mathrm{cycles} / \mathrm{m}$; therefore, it is the same signal as analyzed by 
Table 2. Summary of the significant frequencies (in cycles/m) of the selected spectra shown in Figure 6 and corresponding ratios of spectral peaks.

\begin{tabular}{|c|c|c|c|c|c|c|}
\hline \multirow{2}{*}{$\begin{array}{l}\text { Depth } \\
\text { (mbsf) }\end{array}$} & \multicolumn{3}{|c|}{ Frequency (cycles/meter) } & \multicolumn{3}{|c|}{ Ratios of spectral wavelengths } \\
\hline & 413 k.y. & 123 k.y. & 95 k.y. & $413 / 123$ k.y. & $413 / 95$ k.y. & 123/95 k.y. \\
\hline 39.7 & 0.222 & 0.730 & 0.952 & 0.304 & 0.233 & 0.767 \\
\hline 46.9 & 0.222 & 0.717 & 0.939 & 0.310 & 0.236 & 0.764 \\
\hline 56.0 & 0.222 & 0.717 & 0.926 & 0.310 & 0.240 & 0.774 \\
\hline 65.0 & 0.208 & 0.704 & 0.900 & 0.295 & 0.231 & 0.782 \\
\hline 74.1 & 0.208 & 0.704 & 0.887 & 0.295 & 0.234 & 0.794 \\
\hline 83.1 & 0.313 & 0.991 & 1.292 & 0.316 & 0.242 & 0.767 \\
\hline 392.2 & 0.313 & 1.004 & 1.304 & 0.312 & 0.240 & 0.770 \\
\hline 401.2 & 0.339 & 1.148 & 1.448 & 0.295 & 0.234 & 0.793 \\
\hline 410.3 & 0.352 & 1.161 & 1.436 & 0.303 & 0.245 & 0.808 \\
\hline 419.3 & 0.365 & 1.173 & 1.548 & 0.311 & 0.236 & 0.758 \\
\hline 428.4 & 0.169 & 0.561 & 0.717 & 0.301 & 0.236 & 0.782 \\
\hline \multicolumn{4}{|c|}{ Expected ratios: } & 0.300 & 0.232 & 0.772 \\
\hline & \multicolumn{6}{|c|}{ Other peak values (cycles/meter) } \\
\hline 339.7 & 0.417 & 0.548 & 0.834 & 1.134 & 1.343 & \\
\hline 346.9 & 0.352 & 0.443 & 0.521 & 1.148 & 1.369 & \\
\hline 365.0 & 0.495 & 1.082 & 1.226 & 1.369 & & \\
\hline 365.0 & 0.365 & 0.495 & 1.082 & 1.226 & 1.408 & \\
\hline 374.1 & 0.313 & 0.508 & 1.069 & 1.239 & 1.382 & 1.474 \\
\hline 383.1 & 0.182 & 0.482 & 0.548 & 0.678 & 0.769 & 1.161 \\
\hline 392.2 & 0.182 & 0.548 & 0.80 & 1.161 & & \\
\hline 401.2 & 0.182 & 0.456 & 0.652 & 0.743 & 0.834 & 0.991 \\
\hline 410.3 & 0.156 & 0.652 & 0.861 & 1.004 & 1.148 & \\
\hline 419.3 & 0.156 & 0.287 & 0.561 & 0.678 & 0.861 & 1.421 \\
\hline 428.4 & 0.378 & 0.861 & & & & \\
\hline
\end{tabular}

Notes: The ratios of the spectral peaks display consistent matches with 413 k.y., 123 k.y., and 95 k.y. Milankovitch eccentricity cycles regardless of changing sedimentation rates. Other peak frequencies (in cycles/meter) identified in these are in the lower table.

spectral analysis. In addition to high-frequency peaks, the gammaray trace displays relative concentrations of peaks and of troughs with about 4- to 5-m spacing. A sinusoid curve was generated and stretched on an interactive graphics terminal until a visual fit was obtained to the clusters of high/low intensity peaks. The resulting 4- $\mathrm{m}$ wavelength sine-curve is in phase for most of the major peaks, but has an interval of mismatch at about 355 mbsf in the center of the window (Fig. 9). We estimate that the dominant long-period cyclicity in this interval corresponds to an average wavelength of between 4 and $4.5 \mathrm{~m}$. The mismatch at $355 \mathrm{mbsf}$ may be due to an interruption in sedimentation.

The corresponding spectral analysis of this window displays a broad "413-k.y." peak with the center corresponding to about 4.0 to $4.8 \mathrm{~m}$ (Fig. 10). Therefore, the visual fit to the gamma-ray signal is consistent with the spectral analysis computation, but the visual fit yielded a sinusoid having a wavelength about $10 \%$ shorter than the main spectral peak. The "413-k.y." spectral peak incorporates wavelengths from approximately $4.81 \mathrm{~m}$ to $3.65 \mathrm{~m}$. These multiple wavelengths will have a destructive superposition, thereby modeling the apparent phase shift and the mismatch in the middle of the 40-m window of our simple "best-fit" 4-m sinusoid. Therefore, spectral analysis will not necessarily compute the dominant cyclicity within a given interval if that window incorporates an apparent interruption in the cyclic sedimentation, but will model the cyclicity as a broadened cluster of frequencies. Presumably, if a series of narrow subwindows were applied to this $40-\mathrm{m}$ main window, a sharper cycle peak would be identified.

Within this $40-\mathrm{m}$ window, the gamma-ray signal displays an average of three separate peaks comprising each of the "413-k.y." clusters. These 1-m spaced peaks correspond to the "95-123 k.y." cycles (dominant $1.11-\mathrm{m}$ and lesser $1.42-\mathrm{m}$ wavelengths) yielded by the spectral analysis (Fig. 10).

\section{Comparison of Spectral Cyclicity of a 40-m Window with Formation MicroScanner Imagery}

Next, we correlated these individual peaks and peak clusters of gamma-ray logging signal to the Formation MicroScanner imagery of the sedimentary strata in order to identify the sediment features responsible for generating the apparent cyclicity.

The process of "de-meaning" the gamma-ray log trace removed large-scale intensity features with wavelengths exceeding $10 \mathrm{~m}$, leaving the higher frequency fluctuations within such broader general trends (Fig. 4). Unfortunately, these large-scale general trends are the features most immediately apparent in the lithology record (Table 1) and in the Formation MicroScanner imagery.

Peaks of gamma-ray intensity generally correspond to intervals of relatively high clay content. The Formation MicroScanner log have low-resistivity for either high-clay or poorly-consolidated clayey radiolarite intervals (Serra, 1989). The main features on the Formation MicroScanner imagery of Hole 801B are silicified zones, which are displayed as high-contrast "white" beds on the processed images (Molinie and Ogg, this volume). Therefore, intervals of high gammaray intensity usually correspond to low-resistivity, or "black," features on Formation MicroScanner images. The best visual comparisons is matching negative peaks of low intensities of gamma rays to corresponding high-resistivity "white" silicified zones. There is not a direct relationship between the response of gamma-ray logs and of resistivity logs; therefore, care must be taken in directly matching features on Formation MicroScanner resistivity imagery to the gamma-ray intensity $\log$ fluctuations.

The main broad high- and low-intensity features of the un-demeaned original trace of the gamma-ray log (Fig. 4) can be matched to zones of low- and high-resistivity on the Formation MicroScanner imagery which are interpreted to be clay-rich or partially silicified layers, respectively. Detailed "bed-by-bed" Formation MicroScanner descriptions are in Molinie and Ogg (this volume). However, this gamma-ray correlation reveals that most features on the Formation MicroScanner imagery have approximately a 1-m downward offset relative to the independent gamma-ray log run. In detail, there is up to a 1-m fluctuation in this depth correspondence, probably as a result of heave-jerks in both logging runs. Such irregular displacements may contribute to the broadening of spectral peaks, especially the 123-k.y. and 95-k.y. cycles.

It appears that the "de-meaning" procedure, which was applied in a downhole direction, emphasizes the highest occurrence of two adjacent equal-intensity peaks in the gamma-ray trace. As a result, a cluster of high peaks on the de-meaned signal indicates the upper portion of a silica-rich interval, but not the actual maximum of silicification. This downward compensation for long-term trends has implications for the correlation of cycles with lithology, because there is a skewness toward the "top" of trends. It is suggested that, in future processing of ODP logging data, the de-meaning procedure be run "uphole" so that cycle changes can be examined "forward-in-time" (i.e., from a geological viewpoint) and compared later to an independent "downhole" de-meaned analysis.

Within this 40- $\mathrm{m}$ window, events of relatively greater silicification (looking "downhole") corresponding to the "413-k.y" cycle of gamma-ray peaks are: (1) $347 \mathrm{mbsf}$, the top of thin-bedded siliceous banding below a major clay-rich zone; (2) $352 \mathrm{mbsf}$, very siliceous band near the top of a major chert-rich zone; (3) $356 \mathrm{mbsf}$, highsiliceous pulse near base of the same chert-rich zone (the fixed sinusoid of Fig. 9 is out of phase for this and the following peak, which may indicate a minor discontinuity in sedimentation); (4) 359 mbsf, a set of siliceous bands within an overall clay-rich interval; (5) $362.6 \mathrm{mbsf}$, extremely siliceous pulse near the base of a generally very siliceous zone; (6) $367.4 \mathrm{mbsf}$, concentration of siliceous bands at top of a major pulse of silicification underlying a clay-rich zone; (7) 373 mbsf, a large siliceous band within a generally clay-rich 


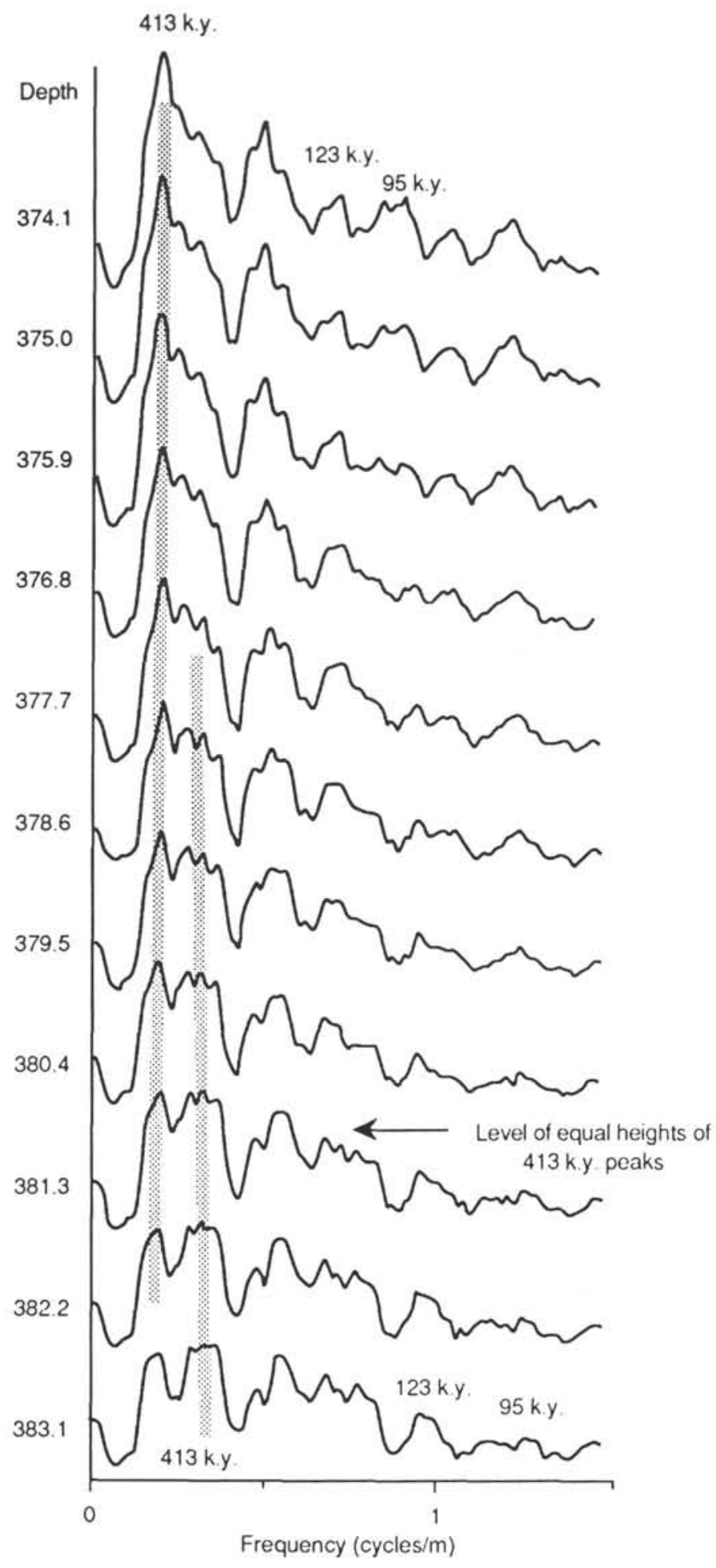

Figure 7. Determination of the discontinuity in sedimentation rate occurring between 374.1 and $383.1 \mathrm{mbsf}$. Power spectra of a series of overlapping 40 -m-wide depth windows at 0.9 -m increments. The 40 - $\mathrm{m}$ window displaying spectral peaks of equal amplitude for the "413-k.y." eccentricity cycle is marked. The corresponding short-period cycles of "123 k.y." and "95 k.y." undergo similar but less visually distinct replacements. interval; and (8) 377 mbsf, a minor siliceous band within the same clay-rich interval which appears significant "looking down," but actually is slightly thinner and less siliceous relative to the next two underlying bands.

In summary, the "413-k.y." cyclicity is displayed on the Formation MicroScanner imagery as pulses of increased silicification relative to the general sedimentation. These pulses are relatively narrow, commonly less than $0.5 \mathrm{~m}$ thick, and can be comprised of one to three close-spaced bands of silicification. Between these major "413-k.y." pulses, which are spaced at about 4- to 5-m intervals within this window, are lesser pulses of silicification at about $1.0-$ to $1.5-\mathrm{m}$ spacing, corresponding to the combined "95-k.y. and 123-k.y." cycles. The "413-k.y." cycle is generally displayed as a periodic enhancement of this 1-m cyclicity.

On the gamma-ray intensity log, clay-rich "positive" peaks have importance equal to the negative peaks caused by pulses of silicification, which are presumably caused by higher radiolarian contents. Peaks of clay enrichment are not as apparent on the Formation MicroScanner imagery, probably due to the lack of resistivity contrasts between clayey radiolarite and radiolarian claystone. Clay-enrichment peaks have the same periodicity as the pulses in silicification. In general, this radiolarite facies oscillates between enhanced clay content and enhanced silicification with a combined cyclicity at the "95-123413 k.y." wavelengths.

Within each individual "95-123-k.y." eccentricity cycle of approximately $1-\mathrm{m}$ wavelength are generally several minor fluctuations in radiolarian/clay ratio. These high-frequency features are expressed in the recovered cores as varying degrees of partial silicification (chert or porcellanite) and in the Formation MicroScanner imagery as bands or lenses of variable resistivity (Molinie and Ogg, this volume). The $15-$ to $20-\mathrm{cm}$ spacing of these silicification features in the lower portion of this interval could be partially caused by Milankovitch precession cycles of 19- to 23-k.y. periods, but the 5-cm spacing of silicification bands in the upper portion of this intervals would appear to be too thin to represent precession cycles and perhaps may partially represent an inherent scale of diagenetic processes.

\section{"Tuned" Sedimentation Rates and Discontinuities Correlated to the Stratigraphy of Site 801}

The eccentricity cycles from the logs indicate that the Callovian through Valanginian sediments of Site 801 consist of three main intervals, having relatively constant sedimentation rates, separated by discontinuities. These intervals and horizons correspond to lithologies and breaks in the stratigraphy of Site 801 (Fig. 11).

\section{412 to $448 \mathrm{mbsf}$}

Sedimentation rates for this interval, as computed from spectral analysis, are approximately $14.5 \mathrm{~m} / \mathrm{m}$.y. However, the spectral peaks for these lowermost windows are not as well defined, and this "tuned" sedimentation rate appears to be incompatible with stratigraphic constraints (Ogg et al., this volume). The sedimentation rates would imply that this $36-\mathrm{m}$ interval represents only about $2.5 \mathrm{~m}$.y. of geological time, which is difficult to reconcile with the radiolarian biostratigraphy. This interval, corresponding to Cores 129-801B-27R through -33R, consists of the lower two-thirds of lithologic Subunit IVB (Oxfordian through Kimmeridgian) of dark chert and brown clayey radiolarite and of the uppermost core of lithologic Unit V (Callovian) of red radiolarite. According to constraints from biostratigraphy, the estimated sedimentation rate for this interval is approximately $4 \mathrm{~m} / \mathrm{m}$.y. Either there are several unrecognized hiatuses in sedimentation present within this interval or else the assignment of cycle peaks and implied sedimentation rates are incorrect in this short, lowermost interval. 


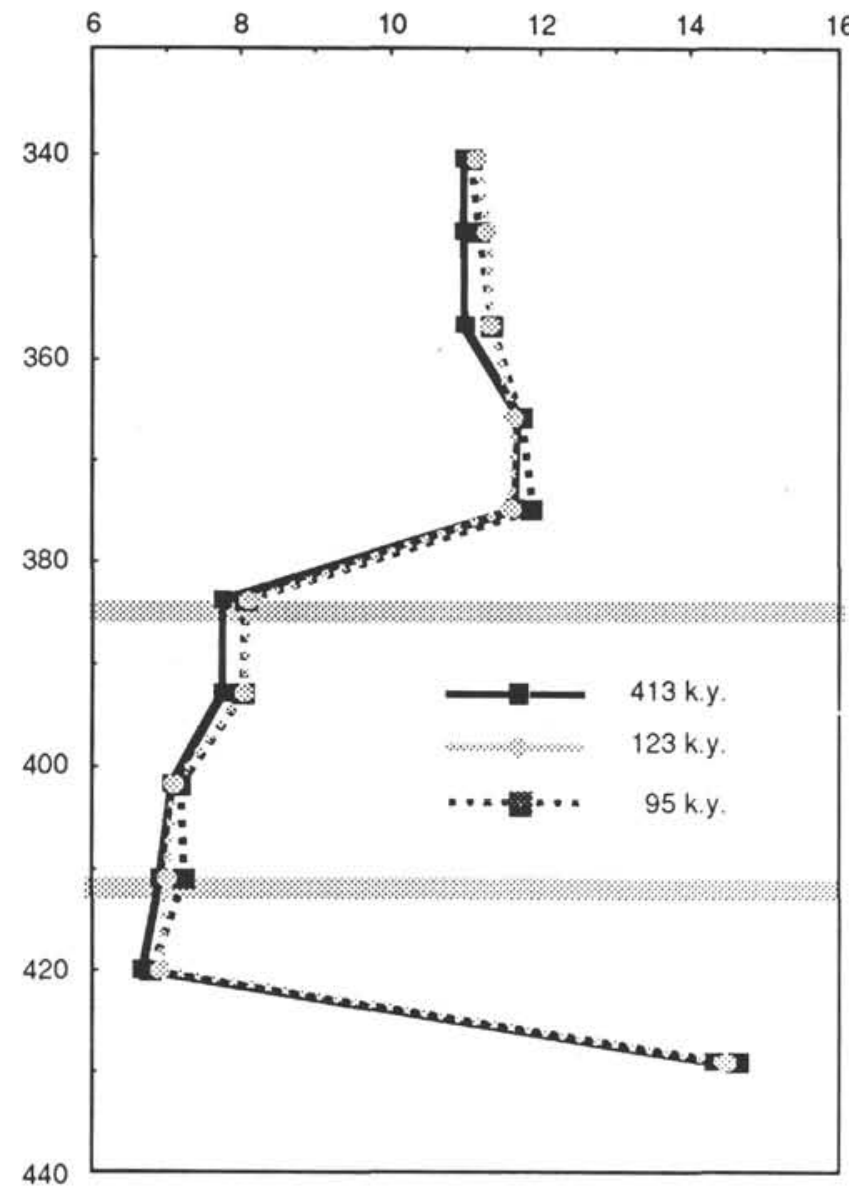

Depth

(mbsf)

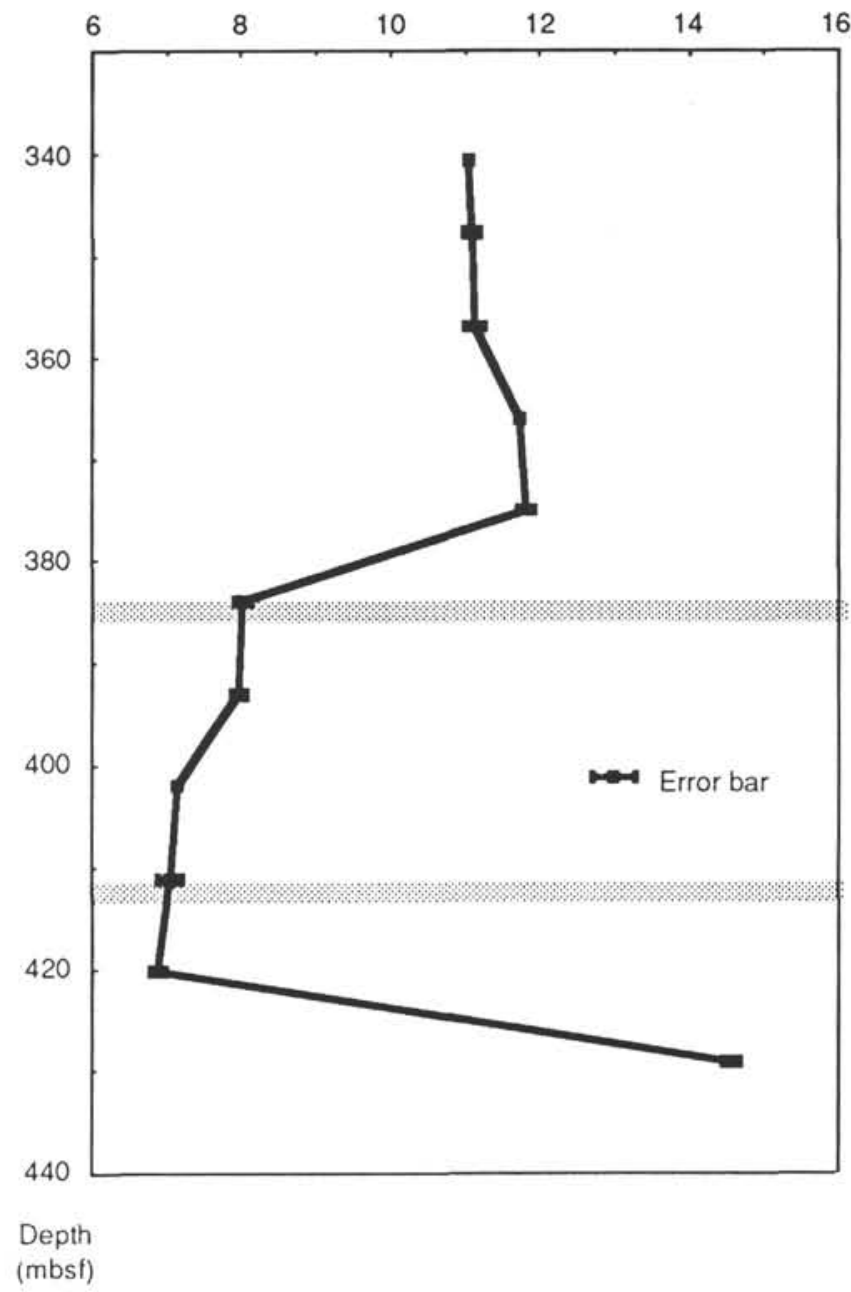

Figure 8. Sedimentation rate curve of Upper Jurassic-Lower Cretaceous radiolarites of Hole 801B computed independently for each peak, assigned to the 413-123 and 95-k.y. eccentricity cycle set, and as the mean for the set. At each depth, the sedimentation rates computed from the individual peaks coincide, implying that the temporal ratio of these peaks remains constant and is independent of sedimentation rate. This constant ratio is evidence that these spectral peaks result from Milankovitch eccentricity cycles.

\section{2. $412 \mathrm{mbsf}$}

This level is an apparent discontinuity from underlying higher sedimentation rates to overlying slower $(6.5 \mathrm{~m} / \mathrm{m} . \mathrm{y}$.) sedimentation rates. This horizon corresponds to the boundary between Cores 129-801B-27R and -26R, which displays a upward change from chert-rich radiolarite to clay-rich radiolarite (Fig. 11), and correlates to a change on geochemical logs from silica-rich to clay-rich sediment (see Appendix, Table 1). Therefore, this discontinuity in sedimentation rates appears to correspond to a sharp upward reduction in radiolarian abundance and has an age of early Tithonian (Shipboard Scientific Party, 1990c; Ogg et al., this volume).

\section{385 to $412 \mathrm{mbsf}$}

Sedimentation rates for this interval, as computed from spectral analysis, are relatively slow, averaging approximately $7 \mathrm{~m} / \mathrm{m}$.y. There is some indication that the lower portion, from $412 \mathrm{mbsf}$ to $398 \mathrm{mbsf}$, has a slower rate compared to $398-385 \mathrm{mbsf}$ ( $6.5 \mathrm{vs} .7 .5 \mathrm{~m} / \mathrm{m} . \mathrm{y}$.) (Fig. 8). The lower interval corresponds to the pronounced clay-rich radiolarite of Cores 129-801B-26R to -24R (upper Subunit IVB, early
Tithonian). The upper interval corresponds to the banded chert facies of Cores 129-801B-23R to -20R (lower Subunit IVA, middle Tithonian). The estimated sedimentation rate for this interval from shipboard stratigraphy is approximately $6 \mathrm{~m} / \mathrm{m}$.y., consistent with this cycle analysis. The implied duration of this $27-\mathrm{m}$ interval is $4 \mathrm{~m} . \mathrm{y}$., or approximately half of the Tithonian stage. The similarity in sedimentation rates between the clay-rich lower portion and the chert-rich upper portion is probably a coincidence and distorted by associated differences in bulk density, but suggests that clay influx diminished simultaneously with an increase in radiolarian input.

\section{4. $385 \mathrm{mbsf}$}

This level is an apparent discontinuity from underlying slower sedimentation rates to overlying higher rates $(11.5 \mathrm{~m} / \mathrm{m} . \mathrm{y}$.). This depth corresponds to the sharp upward change on the geophysical logs from banded chert to clay-rich radiolarite (386 mbsf on gammaray, 379 mbsf on geochemical, 378 mbsf on Formation MicroScanner) and to a probable hiatus between the Tithonian and the Berriasian-Valanginian stages at the Jurassic-Cretaceous boundary (Ogg et al., this volume). 


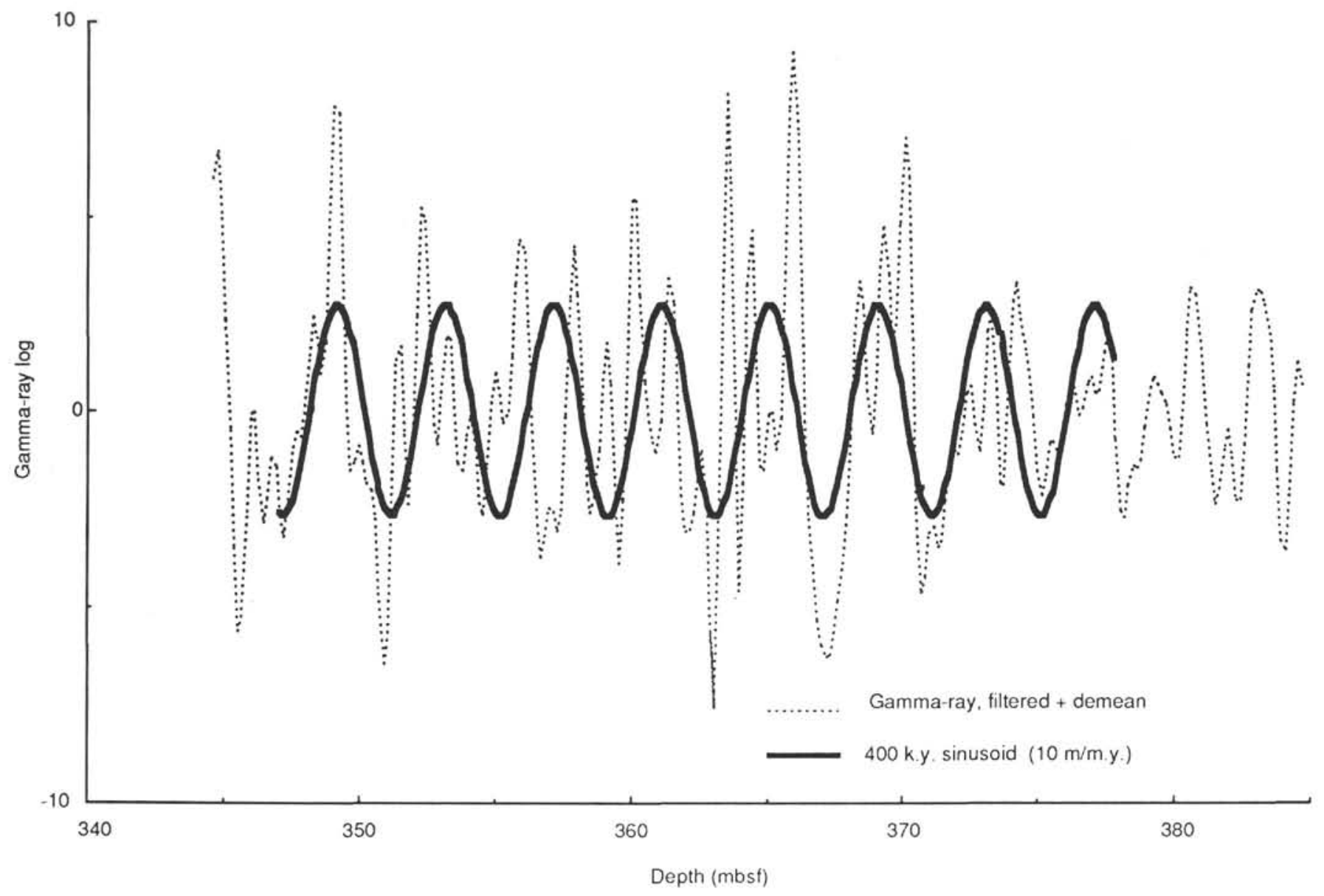

Figure 9. Processed gamma-ray intensity signal (filtered and de-meaned) from the $345-385$ mbsf interval with a visual match of the main features to a synthetic sinusoid having a $4-\mathrm{m}$ wavelength. This sinusoid match corresponds approximately to a $400-\mathrm{k} . \mathrm{y}$. with a $10-\mathrm{m} / \mathrm{m}$.y. sedimentation rate (see Fig. 10).

\section{318 to $385 \mathrm{mbsf}$}

Sedimentation rates for this interval, as computed from spectral analysis, are relatively rapid, averaging approximately $11.5 \mathrm{~m} / \mathrm{m} . \mathrm{y}$. This interval corresponds to the brown clayey radiolarite with abundant dark brown chert of upper Subunit IVA (Cores 129-801B-14R through -20R; undifferentiated Berriasian to mid-Valanginian age). An increased input of clay and possible lesser increase in radiolarian influx is presumed to be the cause of this acceleration in sedimentation rate relative to the underlying bedded chert, in addition to the lesser degree of compaction and lithification. The estimated sedimentation rate from shipboard stratigraphy was $7 \mathrm{~m} / \mathrm{m}$.y. or higher. The implied duration of this $67-\mathrm{m}$ interval is approximately $6 \mathrm{~m} . \mathrm{y}$. and would imply that much of the upper Berriasian and lower Valanginian stages are present, which is consistent with the available biostratigraphy.

In general, the average rates and discontinuities in sedimentation, as computed from spectral analysis of cycles, are generally consistent with the stratigraphy of Site 801. The only exception is the high sedimentation rates computed for the lowermost interval which may be an artifact of inadequate data. It should be noted that these sedimentation rates are the rates of steady-state accumulation of lithified sediment. Hiatuses within an interval of otherwise constant sedimentation rates would not be detected by spectral analysis. Therefore, the average sedimentation rates, even within the individual windows, may be less than indicated by the typical spacing of cycles. Such a minor hiatus, then resumption of a similar sedimentation rate is suspected within the window examined in Figure 10.
The average sedimentation rate calculated for the partly silicified clayey radiolarite of upper lithologic Subunit IVA is $11.5 \mathrm{~m} / \mathrm{m} . y$., and for the interval of banded chert of lower Subunit IVA is $7.5 \mathrm{~m} / \mathrm{m}$.y. Apparent average sedimentation rates estimated for Jurassic-Cretaceous bedded radiolarian cherts exposed in other regions have a considerable range (Matsuda and Isozaki, 1991). This wide range in sedimentation rates may be partially due to different origins of banded radiolarites (Jones and Murchey, 1986), to variable influx and preservation of radiolarians (only a small percentage of radiolarians arriving on the seafloor escape dissolution before burial), and to the 4-5 compaction factor during the conversion from unconsolidated radiolarite to a radiolarian chert (Hein and Karl, 1983). Estimates of apparent average sedimentation rates for radiolarian cherts range from 0.5-0.7 m/m.y. for exposures in Baja California (Sedlock and Isozaki, 1990), 0.7-1.0 m/m.y. for sections in the Austrian Alps (Garrison and Fischer, 1969), 0.4-5.0 m/m.y. for southwestern Japan (Matsuda and Isozaki, 1991), 3.3-6.2 m/m.y. for northern Italy (Kocher, 1981) and 3-9 m/m.y. for the Eastern Alps (Schlager and Schlager, 1973). Jenkyns and Winterer (1982) and Jenkyns (1986) compiled various Mesozoic ribbon radiolarite and Cenozoic marginal sea siliceous ooze deposition rates ranging from about 1 to $9 \mathrm{~g} / \mathrm{cm}^{2} / 10^{3} \mathrm{yr}$, or approximately equivalent to a range of 4 to $30 \mathrm{~m} / \mathrm{m}$.y. Therefore, the computed sedimentation rates of 7-12 $\mathrm{m} / \mathrm{m}$.y. for the clayey radiolarite and banded chert facies of Site 801 are consistent with deposition rates of other radiolarites.

The apparent absence of turbidite or redeposition features in any of the recovered Upper Jurassic-Lower Cretaceous cores may indicate that the site was drilled on a relative local high. If true, then 


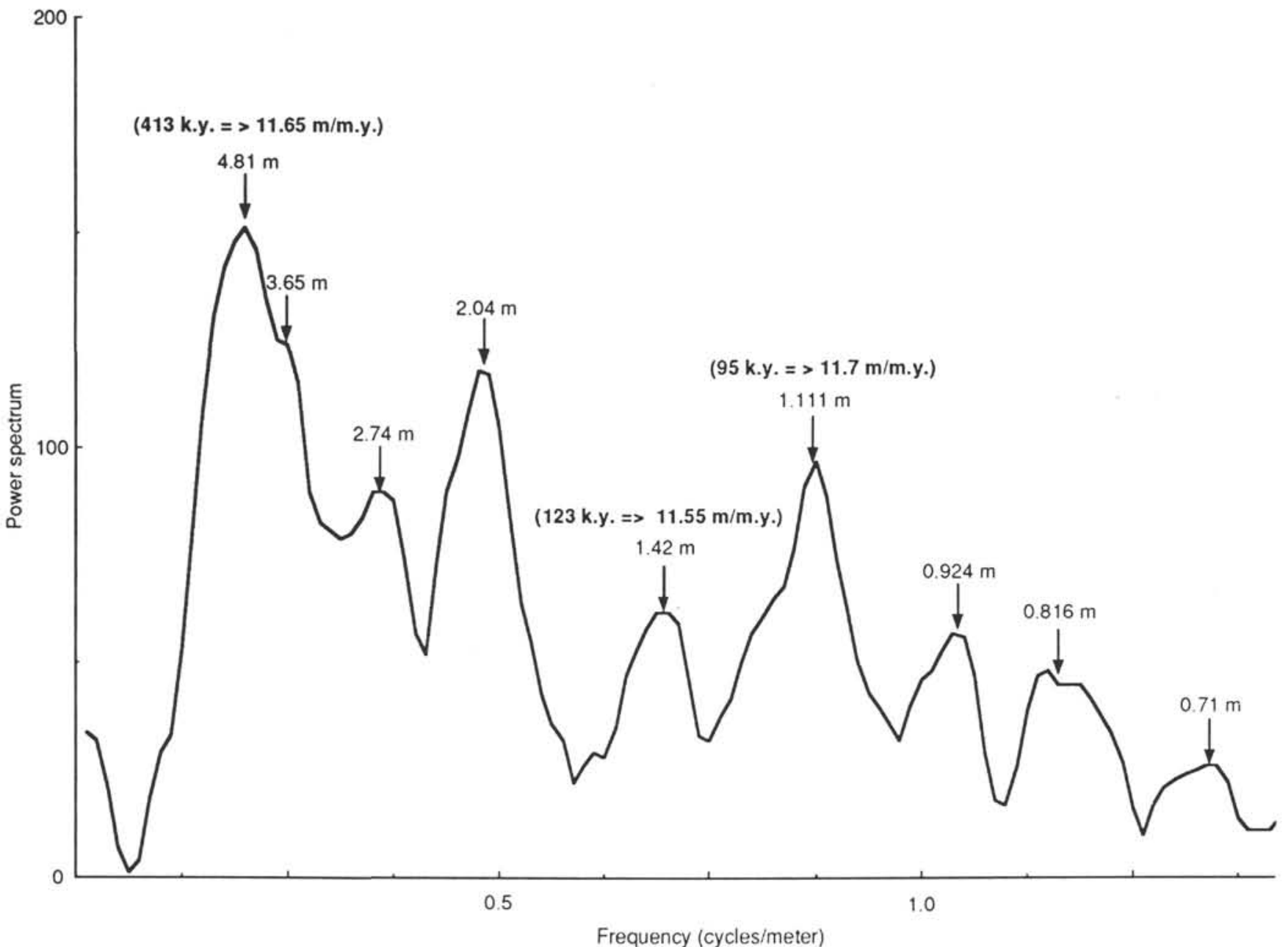

Figure 10. Spectrum analysis on the selected window (345-385 mbsf) displayed in Figure 9. Wavelengths of major peaks and corresponding sedimentation rates implied by the assigned eccentricity cycles are indicated. The additive effect of the two spectral components of 4.81 - and 3.85 -m wavelength yields the average 4-m period identified by the visual match of a sinusoid to the initial gamma-ray intensity signal. Mean sedimentation rate implied by the assigned eccentricity periods is $11.6 \mathrm{~m} / \mathrm{m} . \mathrm{y}$.

perhaps the apparent mismatch of "sedimentation rates" from spectral analysis and "net accumulation rates" from biostratigraphy may be partially due to presence of minor slump-removal episodes within the stratigraphic column. Such a disruption in the cyclicity is apparent in the window of Figure 9. The spectral analysis results indicate that actual sedimentation (after lithification) was about $10 \mathrm{~m} / \mathrm{m} . \mathrm{y}$. , which suggests that as much as half of this accumulation may have been removed in minor and major episodes. No turbidites are noted at this site until the ?Hauterivian, above a "hardground" layer of Valanginian (Ogg et al., this volume).

\section{CONCLUSIONS}

1. Geophysical logs of the Jurassic and Lower Cretaceous radiolarites of Site 801 display cyclic variations in clay content and silicification. Three-dimensional spectral analysis of a sliding 40-m window through this $130-\mathrm{m}$ interval yielded dominant peaks having wavelength ratios which consistently matched the ratios expected from the set of 413-12395 k.y. Milankovitch eccentricity cycles.

2. Corresponding mean sedimentation rates computed from these interpreted Milankovitch eccentricities range from $11.5 \mathrm{~m} / \mathrm{m} . \mathrm{y}$. for the Berriasian-Valanginian, $7 \mathrm{~m} / \mathrm{m}$.y. for the Tithonian, and an uncertain $14.5 \mathrm{~m} / \mathrm{m}$.y. for the Oxfordian-Kimmeridgian. These sedimentation rates are higher than those initially estimated from the shipboard stratigraphy, but with the exception of the oldest interval are consistent with range of biostratigraphic uncertainty and suspected presence of major hiatuses in the section. The sedimentation rates are within the range of radiolarite sediments exposed in other regions.

3. The three-dimensional spectral analysis of the gamma-ray logs indicates discontinuities where one set of peaks diminishes with depth simultaneously with the appearance of another set, which retained the same ratio of wavelengths. These discontinuities reflect sharp changes in sedimentation rate occurring at approximately $412 \mathrm{mbsf}$ and $385 \mathrm{mbsf}$. The lower discontinuity corresponds to a rapid upward change from chert-rich radiolarite to clay-rich radiolarite, and approximately to the Kimmeridgian-Tithonian boundary. The upper discontinuity corresponds to the change from bedded chert to overlying radiolarian claystone, and to a probable hiatus at the boundary between the Tithonian and the Berriasian-Valanginian.

4. The Milankovitch eccentricity cycles were matched to features on the high-resolution Formation MicroScanner resistivity imagery. The presumed "123-k.y. and 95-k.y." cycles occur as chert bands or concentrations of increased silicification of the sediment. The "413-k.y." cycle is displayed as an additional accentuation of this periodic silicification. The major silicification intervals are possibly where the "95-123-k.y." and "413-k.y." cycles are in phase, thereby resulting in high-silica peaks against a generally high-silica "background." The gamma-ray intensity $\log$ indicates that there are also peaks of clay enrichment, but this 


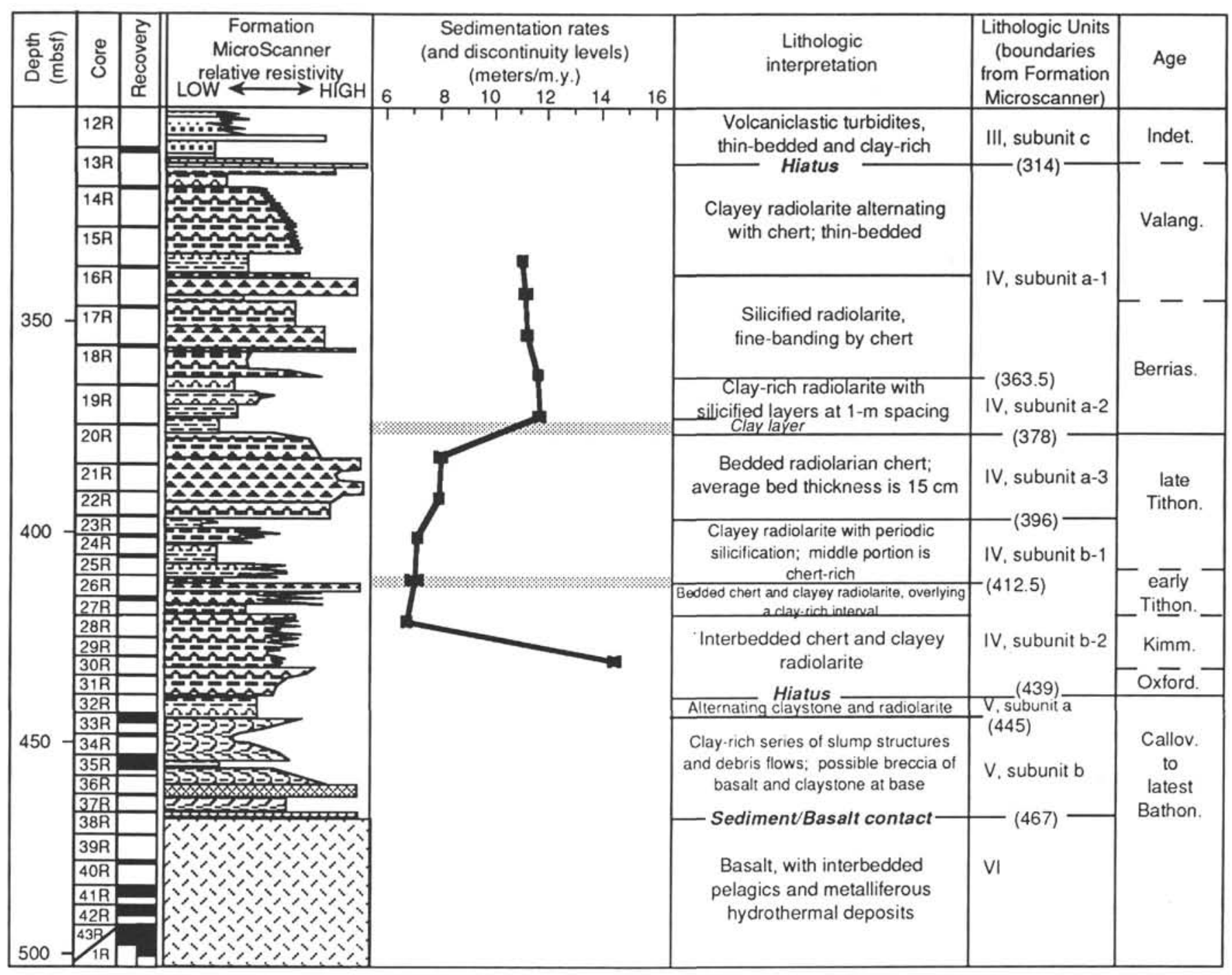

\section{Legend for lithology column}

= Volcaniclastic turbidites
$=$ Well-cemented horizon (hard-ground?) at top of Unit III
$=$ Radiolarian claystone alternating with clayey radiolarite
$=$ Chert alternating with radiolarian claystone
$=$ Chert
$=$ Breccia

Figure 11. Summary of sedimentation rates and discontinuity levels as computed from Milankovitch eccentricity cycles. Stratigraphy of the Jurassic and Lower Cretaceous sediments are from interpretations of Formation MicroScanner resistivity imagery (Molinie and Ogg, this volume) and from core recovery. Sedimentation rates are the mean of a 40-m window centered at the plotted level, and are therefore not necessarily the rate corresponding to the adjacent lithologies. Discontinuities in sedimentation (shaded lines) are computed within the respective windows by adjusting for the different sedimentation rates, as explained in the text. 
characteristic can not be distinguished from poorly cemented radiolarite on the Formation MicroScanner imagery.

5. The Milankovitch cycles are expressed as changing clay/radiolarite ratios, with higher radiolarian contents being manifested as increased silicification of the sediment. These eccentricity cycles occur as medium-frequency features on long-term (10-20 m) trends in the general level of enrichment in clay or radiolarians, which would correspond to oceanographic sedimentation changes on time scales of approximately 1-3 m.y. There is some indication that the "95- and 123-k.y." cycles occur with shorter wavelengths within the broad clay-enriched zones as compared to a longer wavelength within generally radiolarian-enriched zones. This suggests that overall increases in sedimentation rate are generally the result of a higher radiolarian content.

6. Many types of marine and continental sediments record periodic changes in depositional environments caused by Milankovitch climate cycles. Spectral analysis of logging data of these sediments can enable resolution of Milankovitch climatic cycles, thereby providing rates of sedimentation. It is important to verify that the ratios of the vertical wavelengths of such cycles are the same as the ratios of the periods of the corresponding Milankovitch cycles; and preferably at least three such cycle periods should be identified and correlated. Plots of a series of such spectral analyses generated from overlapping sliding windows can be used to identify both gradual changes and sudden discontinuities in sedimentation rates. As sedimentation rate changes, the locations of spectral peaks shift, but the relative ratios within the suite must remain constant. Use of Milankovitch cycles to compute sedimentation rates reduces the need for precise biostratigraphic control and absolute geological time scales, but the biostratigraphic data will still provide the main constraint on the net accumulation curve.

\section{ACKNOWLEDGMENTS}

We thank the Ocean Drilling Program for inviting our participation on Leg 129, our shipboard colleagues for fertilizing imaginations by providing free flow of data and valuable observations, the Borehole Research Group at Lamont-Doherty Geological Observatory for encouraging innovative use of geophysical logs and providing computer and financial support (A.J.M.) and analysis software, the Engineering School of Purdue for providing microcomputers, the U.S. Science Advisory Committee and the Joint Oceanographic Institutions for providing financial support (J.G.O.), and Steve Prensky for inviting us to submit a brief note on this topic for The Log Analyst. This paper was greatly improved by reviews and discussions from Roger Anderson, Robin Reynolds, Brian Wallick, Greg Pouch, William Busch, John Doveton, R.C.A. Peveraro, Edward L. Winterer, Timothy Herbert, and William Ruddiman.

\section{REFERENCES}

Anderson, R.Y., 1984. Orbital forcing of evaporite sedimentation. In Berger, A., Imbrie, J., Hayes, J., Kukla, G., and Saltzman, B. (Eds.), Milankovitch and Climate (Pt. 1): Dordrecht (D. Reidel), 147-162.

Arthur, M. A., Dean, W. E., Bottjer, D., and Scholle, P. A., 1984. Rhythmic bedding in Mesozoic-Cenozoic pelagic carbonate sequences: the primary and diagenetic origin of Milankovitch-like cycles. In Berger, A., Imbrie, J., Hayes, J., Kukla, G., and Saltzman, B. (Eds.), Milankovitch and Climate (Pt. 1): Dordrecht (D. Reidel), 191-222.

Baltuck, M., 1983. Some sedimentary and diagenetic signatures in the formation of bedded radiolarite. In Iijima, A., Hein, J. R., and Siever, R. (Eds.), Siliceous Deposits of the Pacific Region: Amsterdam (Elsevier), 299-315.

- 1987. Geochemistry, carbon and oxygen stable isotope composition and diagenetic textural features of Lower Cretaceous pelagic cyclic sediments from the Western North Atlantic, Deep Sea Drilling Project Hole 603B. In van Hinte, J. E., Wise, S. W., Jr., et al., Init. Repts. DSDP, 93:989-996.

Barron, E. J., Arthur, M. A., and Kauffman, E. G., 1985. Cretaceous rhythmic bedding sequences: a plausible link between orbital variations and climate. Earth Planet. Sci. Lett., 72:327-340.
Baumgartner, P. O., 1984. Middle Jurassic-Early Cretaceous low-latitude radiolarian zonation based on unitary associations and age of Tethyan radiolarites. Eclogae Geol. Helv., 77:729-837.

1987. Age and genesis of Tethyan Jurassic radiolarite. Eclogae Geol. Helv., 80:831-879.

Berger, A., 1984. Accuracy and frequency stability of the Earth's orbital elements during the Quaternary. In Berger, A., Imbrie, J., Hayes, J., Kukla, G., and Saltzman, B. (Eds.), Milankovitch and Climate (Pt. 1): Dordrecht (D. Reidel), 3-39.

Berger, A., Imbrie, J., Hayes, J., Kukla, G., and Saltzman, B. (Eds.), 1984. Milankovitch and Climate (Pts. 1 and 2): Dordrecht (D. Reidel).

Berger, A. L., Loutre, M. F., and Dehant, V., 1989. Influence of the changing lunar orbit on the astronomical frequencies of pre-Quaternary insolation patterns. Paleoceanography, 4:555-564.

Borehole Research Group, 1988. Ocean Drilling Program Wireline Logging Manual: Palisades, NY (Lamont-Doherty Geological Observatory).

Bottjer, D. J., Arthur, M. A., Dean, W. E., Hattin, D. E., and Savarda, C. E., 1986. Rhythmic bedding produced in Cretaceous pelagic carbonate environments: sensitive recorders of climatic cycles. Paleoceanography, 1:467-481.

Cotillon, P., 1984. Tentative world-wide correlation of Early Cretaceous strata by limestone-marl cyclicities in pelagic deposits. Bull. Geol. Soc. Denmark, 33:91-102.

1987. Bed-scale cyclicity of pelagic Cretaceous successions as a result of world-wide control. Mar. Geol., 78:109-123.

Cotillon, P., Ferry, S., Gaillard, C., Jautée, E., Latreille, G., and Rio, M., 1980. Fluctuation des paramètres du milieu marin dans le domaine vocontien (France Sud-Est) au Crétacé inférieur: mise en évidence par l'étude des formations marno-calcaires alternantes. Bull. Soc. Geol. Fr., 22:735-744.

Cotillon, P., and Rio, M., 1984. Cyclic sedimentation in the Cretaceous of Deep Sea Drilling Project Sites 535 and 540 (Gulf of Mexico), 534 (Central Atlantic), and in the Vocontian Basin (France). In Buffler, R. T., Schlager, W., et al., Init. Repts. DSDP, 77: Washington (U.S. Govt. Printing Office), 339-376.

Dean, W. E., Gardner, J. V., and Cepek, P., 1981. Tertiary carbonate-dissolution cycles on the Sierra Leone Rise, eastern Equatorial Atlantic Ocean. Mar. Geol., 39:81-101.

Dean, W. E., Gardner, J. V., Jansa, L. F., Cepek, P., and Seibold, E., 1978. Cyclic sedimentation along the continental margin of northwest Africa. In Lancelot, Y., Seibold, E., et al., Init. Repts. DSDP, 41: Washington (U.S. Govt. Printing Office), 965-989.

de Boer, P. L., 1983. Aspects of Middle Cretaceous pelagic sedimentation in southern Europe; production and storage of organic matter, stable isotopes, and astronomical influences. Geol. Utraiectina, 31.

de Boer, P. L., and Wonders, A.A.H., 1984. Astronomically induced rhythmic bedding in Cretaceous pelagic sediments near Moria (Italy). In Berger, A., Imbrie, J., Hayes, J., Kukla, G., and Saltzman, B. (Eds.), Milankovitch and Climate (Pt. 1): Dordrecht (D. Reidel), 177-190.

Demenocal, P., and Bristow, J. F., 1990. Downhole measurement data as paleoclimate indicators: a Plio-Pleistocene record of Asian eolian dust deposition to the Sea of Japan. AAPG Bull., 74:971.

Dromart, G., 1989. Deposition of Upper Jurassic fine-grained limestones in the western Subalpine Basin, France. Palaeogeogr, Palaeoclimatol., Palaeoecol., 69:23-43.

Fischer, A. G., 1977. Pelagic sediments as clues to Earth behavior. In Pialli, G. (Ed.), Paleomagnetic Stratigraphy of Pelagic Carbonate Sediments. Mem. Soc. Geol. Ital., 15:1-18.

1980. Gilbert-bedding rhythms and geochronology. In Yochelson, E. L. (Ed.), The Scientific Ideas of G. K. Gilbert. Spec. Pap.-Geol. Soc. Am., 183:93-104.

1986. Climatic rhythms recorded in strata. Annu. Rev, Earth Planet. Sci., 14:351-376.

Freeman, T., and Enos, P., 1978. Petrology of Upper Jurassic-Lower Cretaceous limestones, DSDP Site 391. In Benson, W. E., Sheridan, R. E., et al., Init. Repts. DSDP, 44: Washington (U.S. Govt. Printing Office), 463-475.

Garrison, R. E., and Fischer, A. G., 1969. Deep-water limestones of the Alpine Jurassic. In Friedman, G. M. (Ed.), Depositional Environments in Carbonate Rocks. Spec. Publ.-Soc. Econ. Paleontol. Mineral., 14:20-54.

Gilbert, G. K., 1895. Sedimentary measurement of geologic time. J. Geol., 3:121-127.

Golovchenko, X., O'Connell, S. B., and Jarrard, R., 1990. Sedimentary response to paleoclimate from downhole logs at Site 693, Antarctic conti- 
nental margin. In Barker, P. F., Kennett, J. P., et al., Proc. ODP, Sci. Results, 113: College Station, TX (Ocean Drilling Program), 239-251.

Hattin, D. E., 1986. Interregional model for deposition of upper Cretaceous pelagic rhythmites, U.S. Western Interior. Paleoceanography, 1:483-494.

Hays, J. D., Imbrie, J., and Shackleton, N. J., 1976. Variations in the Earth's orbit: pacemaker of the Ice Ages. Science, 194:1121-1132.

Hein, J. R., and Karl, S. M., 1983. Comparisons between open-ocean and continental margin chert sequences. In Iijima, A., Hein, J. R., and Siever, R. (Eds.), Siliceous Deposits of the Pacific Region: Amsterdam, (Elsevier), 25-43.

Herbert, T. D., and D'Hondt, S. L., 1990. Precessional climate cyclicity in Late Cretaceous-Early Tertiary marine sediments: a high resolution chronometer of Cretaceous-Tertiary boundary events. Earth Planet. Sci. Lett., 99:263-275.

Herbert, T. D., and Fischer, A. G., 1986. Milankovitch climatic origin of mid-Cretaceous black shale rhythms in central Italy. Nature, 321:739-743.

Herbert, T. D., Stallard, R. F., and Fischer, A. G., 1986. Anoxic events, productivity rhythms, and the orbital signature in a mid-Cretaceous deepsea sequence from central Italy. Paleoceanography, 1:495-506.

House, M. R., 1985. Anew approach to absolute timescale from measurements of orbital cycles and sedimentary microrhythms. Nature, 315:721-725.

Huang, Z., 1991. Periodicity in Cretaceous Pelagic Sequences [Ph.D. dissert.]. Dalhousie Univ., Halifax, Nova Scotia.

lijima, A., Hein, J. R., and Siever, R. (Eds.), 1983. Siliceous Deposits of the Pacific Region: Amsterdam (Elsevier).

Imbrie, J., Hayes, J., Martinson, D. G., McIntyre, A., Mix, A. C., Morley, J. J., Pisias, N. G., Prell, W. L., and Shackleton, N. J., 1984. The orbital theory of Pleistocene climate: support from a revised chronology of the marine ${ }^{18} \mathrm{O}$ record. In Berger, A., Imbrie, J., Hayes, J., Kukla, G., and Saltzman, B., (Eds.), Milankovitch and Climate (Pt. 1): Dordrecht (D. Reidel), 269-305.

Imbrie, J., and Imbrie, J. Z., 1980. Modelling the climatic response to the orbital variations. Science, 207:943-953.

Janecek, T., and Rea, D. K., 1983. Eolian deposition of the North Pacific Ocean; Cenozoic history of atmospheric circulation. Geol. Soc. Am. Bull. $94: 412-420$

Jansa, L., Enos, P., Tucholke, B. E., Gradstein, F. M., and Sheridan, R. E., 1979 Mesozoic-Cenozoic sedimentary formations of the North American Basin, western North Atlantic. In Talwani, M., Hay, W., and Ryan, W.B.F. (Eds.) Deep Drilling Results in the Atlantic Ocean: Continental Margins and Paleoenvironment. Am. Geophys. Union, Maurice Ewing Ser., 3:1-57.

Jarrard, R. D., and Arthur, M. A., 1989. Milankovitch paleoceanographic cycles in geophysical logs from ODP Leg 105, Labrador Sea and Baffin Bay. In Srivastava, S. P., Arthur, M. A., Clement, B., et al., Proc. ODP, Sci. Results, 105: College Station, TX (Ocean Drilling Program), 757-772.

Jenkyns, H. C., 1986. Pelagic environments. In Reading, H. G. (Ed.), Sedimentary Environments and Facies (2nd ed.): Oxford (Blackwell Scientific), 343-397.

Jenkyns, H. C., and Winterer, E. L., 1982. Palaeoceanography of Mesozoic ribbon radiolarites. Earth Planet. Sci. Lett., 60:351-375.

Jones, D. L., and Murchey, B., 1986. Geologic significance of Paleozoic and Mesozoic radiolarian chert. Annu. Rev. Earth Planet. Sci., 14:455-492.

Kanasewich, E. R., 1981. Time Sequence Analysis in Geophysics: Edmonton, Canada (Univ. of Alberta Press)

Kent, D. V., and Gradstein, F. M., 1985. A Cretaceous and Jurassic geochronology. Geol. Soc. Am. Bull., 96:1419-1427.

Kocher, R. N., 1981. Biochronostratigraphische untersuchungen oberjurassischer radiolarienfuehrender gesteine, insbesondere der sudalpen [Ph.D. dissert.]. Eidgenossische Technische Hochschule, Zürich.

Kominz, M. A., and Pisias, N. G., 1979. Pleistocene climate: deterministic or stochastic? Science, 204:171-173.

Lancelot, Y., Hathaway, J. C., and Hollister, C. D., 1972. Lithology of sediments from the western North Atlantic. In Hollister, C. D., Ewing, J. I., et al., Init. Repts. DSDP, 11: Washington (U.S. Govt. Printing Office), 901-949.

Larson, R. L., Moberly, R., et al., 1975. Init. Repts. DSDP, 32: Washington (U.S. Govt. Printing Office).

Leinen, M., 1989. The pelagic clay province of the North Pacific Ocean. In Winterer, E. L., Hussong, D. M., and Decker, R. W. (Eds.), The Geology of North America (Vol. N): The Eastern Pacific and Hawaii: Boulder, CO (Geol. Soc. Am.), 323-335.

Maasch, K. A., and Saltzman, B., 1990. A low-order dynamical model of global climatic variability over the full Pleistocene.J. Geophys. Res., 95:1955-1963.

Matsuda, T., and Isozaki, Y., 1991. Well-documented travel history of Mesozoic pelagic chert in Japan: from remote ocean to subduction zone. Tectonophysics, 10:475-499.

Matsuoka, A., and Yao, S., 1985. Latest Jurassic radiolarians from the Torinos Group in Southwest Japan. J. Geosci., Osaka City Univ., 28:125-145.
1986. A newly proposed radiolarian zonation for the Jurassic of Japan. Mar. Micropaleontol., 11:91-106.

McBride, E. F., and Folk, R. L., 1979. Features and origin of Italian Jurassic radiolarites deposited on continental crust. J. Sediment. Petrol., 49:837-868.

McIntyre, A., Ruddiman, W. F., Karlin, K., and Mix, A. C., 1989. Surface water response of the equatorial Atlantic Ocean to orbital forcing. Paleoceanography, 4:19-55.

Milankovitch, M., 1920. Théorie Mathématique des Phénomènes Thermiques Produits par la Radiation Solaire. Acad. Yougoslave des Sciences et des Arts de Zagreb, Gauthier-Villars, Paris.

1941. Kanon der Erdbestrahlung und seine Anwendung auf das Eiszeitenproblem. Acad. Royale Serbe, Belgrade, Edition Spec. 133. (English translation Cannon of Insolation and the Ice Age Problem, Israel Program for Scientific Translation, Jerusalem, published for the U.S. Dept. of Commerce and Nat. Sci. Found., 1969)

Molinie, A. J., Ogg, J. G., and Ocean Drilling Program Leg 129 Scientific Party, 1990. Sedimentation rate curves and discontinuities from slidingwindow spectral analysis of logs. Log Analyst, 31:370-374.

Mwenifumbo, C. J., and Blangy, J. P., 1991. Short-term spectral analysis of donwhole logging measurements from Site 704. In Ciesielski, P.F., Kristoffersen, Y., et al., Proc. ODP, Sci. Results, 114: College Station, TX (Ocean Drilling Program), 577-585.

Nobes, D. C., Bloomer, S. F., Mienert, J., and Westall, F., 1991. Milankovitch cycles and nonlinear response in the Quaternary record in the Atlantic sector of the Southern Oceans. In Ciesielski, P. F., Kristoffersen, Y., et al., Proc. ODP, Sci. Results, 114: College Station, TX (Ocean Drilling Program), 551-576.

Ogg, J. G., Haggerty, J., Sarti, M., and von Rad, U., 1987. Lower Cretaceous pelagic sediments of Deep Sea Drilling Project Site 603, western North Atlantic: a synthesis. In van Hinte, J. E., Wise, S. W., Jr., et al., Init. Repts. DSDP, 93: Washington (U.S. Govt. Printing Office), 1305-1331.

Oglesby, R. J., and Park, J., 1989. The effect of precessional insolation changes on Cretaceous climate and cyclic sedimentation. J. Geophys. Res., 94:14793-14816.

Olsen, P. E., 1986. A 40-million-year lake record of early Mesozoic orbital climate forcing. Science, 234:842-844.

Palmer, A. R. (comp.), 1983. The Decade of North American Geology 1983 geologic time scale. Geology, 11:504.

Park, J., and Herbert, T. D., 1987. Hunting for paleoclimatic periodicities in a geologic time series with an uncertain time scale. J. Geophys, Res., 92:14027-14040.

Pisias, N. G., and Mix, A. C., 1988. Aliasing of the geologic record and the search for long-period Milankovitch cycles. Paleoceanography, 3:613-619.

Pisias, N. G., and Moore, T. C., Jr., 1981. The evolution of Pleistocene climate: a time series approach. Earth Planet. Sci. Lett., 52:450-459.

Pratt, L. M., 1981. A paleo-oceanographic interpretation of the sedimentary structures, clay minerals, and organic matter in a core of the Middle Cretaceous Greenhorn Formation near Pueblo, Colorado [Ph.D. dissert.] Princeton Univ., Princeton. NJ.

Pratt, L. M., and King, J. D., 1986. Variable marine productivity and high eolian input recorded by rhythmic black shales in mid-Cretaceous pelagic deposits from Central Italy. Paleoceanography, 1:507-522.

Raymo, M. E., Ruddiman, W. F., Backman, J., Clement, B. M., and Martinson, D. G., 1989. Late Pliocene variation in northern hemisphere ice sheets and North Atlantic deep water circulation. Paleoceanography, 4:413-446.

Robertson, A.H.F., and Bliefnick, D. M., 1983. Sedimentology and origin of Lower Cretaceous pelagic carbonates and redeposited clastics, Blake-Bahama Formation, Deep Sea Drilling Project Site 534, western Equatorial Atlantic. In Sheridan, R. E., Gradstein, F. M., et al., Init Repts. DSDP, 76 : Washington (U.S. Govt. Printing Office), 795-828.

Sager, W. W., in press. Seamount age estimates from paleomagnetism and their implications for the history of volcanism on the Pacific Plate. In Keating B., and Bolton, B. (Eds.), Geology and Offshore Mineral Resources of the Central Pacific Basin. Circum-Pac. Counc. Energy Mineral Resour., Earth Sci. Ser., 20.

Saltzman, B., and Maasch, K. A., 1988. Carbon cycle instability as a cause of the late Pleistocene ice age oscillations: modeling the asymmetric response. Global Biogeochem. Cycles, 2:177-185.

Schlager, W., and Schlager, M., 1973. Clastic sediments associated with radiolarites (Tauglboden-Schichten, Upper Jurassic, Eastern Alps). Sedimentology, 20:65-89.

Schlumberger, 1987. Log Interpretation Principles/Applications: Houston (Schlumberger Educational Services). 
Schwarzacher, W., 1987. Astronomically controlled cycles in the lower Tertiary of Gubbio (Italy). Earth Planet. Sci. Lett., 84:22-26.

Sedlock, R., and Isozaki, Y., 1990. Lithology and biostratigraphy of Franciscan-like chert and associated rocks in west-central Baja California. Geol. Soc. Am. Bull., 102:852-864.

Serra, O., 1989. Formation MicroScanner Image Interpretation: Houston (Schlumberger Educational Services).

Shipboard Scientific Party, 1973. Site 167. In Winterer, E. L., Ewing, J. E., et al., Init. Repts. DSDP, 17: Washington (U.S. Govt. Printing Office), $145-234$.

, 1990a. Explanatory Notes. In Lancelot, Y., Larson, R. L., et al., Proc. ODP, Init. Repts., 129: College Station, TX (Ocean Drilling Program), 5-29. , 1990b. Site 800. In Lancelot, Y., Larson, R., et al., Proc. ODP, Init. Repts., 129: College Station, TX (Ocean Drilling Program), 33-89.

-, 1990c. Site 801. In Lancelot, Y., Larson, R., et al., Proc. ODP, Init. Repts., 129: College Station, TX (Ocean Drilling Program), 91-170.

Steinberg, M., Bonnot-Courtois, C., and Tlig, S., 1983. Geochemical contribution to the understanding of bedded chert. In Iijima, A., Hein, J. R., and Siever, R. (Eds.) Siliceous Deposits of the Pacific Region: Amsterdam (Elsevier), 193-210.

ten Kate, W. G., and Sprenger, A., 1989. On the periodicity in a calcilutite-marl succession (SE Spain). Cretaceous Res., 10:1-31.

Thiede, J., Vallier, T. L., et al., 1981. Init. Repts. DSDP, 62: Washington (U.S. Govt. Printing Office).

Thomson, D. J., 1982. Spectrum estimation and harmonic analysis. Proc. IEEE, 70:1055-1096.

Date of initial receipt: 16 May 1991

Date of acceptance: 10 February 1992

Ms 129B-142

\section{APPENDIX}

\section{Hole 801B Jurassic and Lower Cretaceous Logging Units and Interpreted Lithologies}

Downhole logging data indicate several distinctive facies shifts within and bounding "logging Unit 3" (313 to 448 mbsf) corresponding to lithologic Unit IV (Shipboard Scientific Party, 1990c). Variable degrees of silification are indicated by the overall character of variable but relatively high resistivity, velocity, resistivity, density and Si concentration, by the decreased content of $\mathrm{Fe}$ and $\mathrm{Al}$ relative to the overlying volcaniclastic turbidites and by the generally low total gamma-ray counts. The aluminum geochemical log, which uses induced gamma-ray spectrometry, has very little variation throughout lith- ologic Unit IV and increases slightly upward into the volcaniclastic turbidites. The silica geochemical log also uses induced gamma-ray emission and is computed aboard ship as an abundance relative to $\mathrm{Fe}, \mathrm{Ca}, \mathrm{S}, \mathrm{Cl}$ and $\mathrm{H}$; hence, it is not an absolute indicator of silica abundance (Schlumberger, 1987; Borehole Research Group, 1988). The Si log can be considered as a measure of chert abundance; however, it does not reliably indicate the abundance of siliceous radiolarians in claystone because there are similar amounts of interstitial water within claystone and within unsilicified radiolarian sand.

The sedimentary column of lithologic Unit IV can be subdivided by the logging data into several distinct intervals and trends, which tend to mirror the poorly recovered core lithologies. These results are summarized in Table 1.

$441-450$ mbsf (base of geochemical logs): Very low Si on geochemical log implying rare chert. This interval is the upper portion of the Callovian Unit $\mathrm{V}$ (red radiolarite interbedded with clay).

413-440 mbsf (Cores 129-801B-27R to - 32R): high Si content corresponds to the chert-rich lower portion of Subunit IVB. This interval has a slight upward increase in $\mathrm{Si}$ and resistivity, implying an upward increase in the relative content of chert.

403-413 mbsf (Cores 129-801B-24R to -26R): Upward shift to clay-rich parameters with very low $\mathrm{Si}$ correlates with the clayey-radiolarite upper portion of Subunit IVB.

379-401 mbsf (lower Cores 129-801B-20R through -23R): High Si and U and low $\mathrm{K}$ and Th, low total gamma ray (possibly downshifted by about $7 \mathrm{~m}$ relative to the zone of Si enrichment), and high density and velocity; coincides closely to the banded chert lower portion of Subunit IVA.

372-379 mbsf (Cores 129-801B-19R to upper-20R): A minor Al peak and high gamma-ray emission was interpreted as "an interval of radiolarite with volcanic clay" (Shipboard Scientific Party, 1990c).

358-372 mbsf (Cores 129-801B-18R to-19R): Relatively clay-rich compared to the overlying interval.

316-358 mbsf (Cores 129-801B-14R to -18R): Lower Th, lower K, lower total gamma ray, and more stable sonic velocity relative to the underlying interval indicates a relatively clay-poor radiolarite. An upward trend in decreasing $\mathrm{Si}$, resistivity, and bulk density is interpreted as an upward decrease in chertification.

314-316 mbsf (corresponding to the middle of Core 129-801B-13R): A sharp pulse of high-emission total gamma ray and resistivity, an upward decrease in $\mathrm{Si}$ and $\mathrm{Th}$, and a rise in $\mathrm{K}$ and $\mathrm{U}$ indicates a sharp boundary of Unit IV to the overlying volcaniclastic turbidites and a probable late Valanginian hiatus.

Bed-by-bed descriptions of the Formation MicroScanner data, discussion of bedding dips, and a stratigraphic column of chert/clay ratios are presented by Molinie and Ogg (this volume). 